\title{
MONOPSONY IN MANPOWER: ORGANIZED BASEBALL MEETS THE ANTITRUST LAWS*
}

For over sixty years professional baseball clubs have disregarded with impunity the mandate of the Sherman Act ${ }^{1}$ that "competition, not combination should be the law of trade."2 By agreeing not to compete for players' services and by blacklisting those players who turn to higher bidders, a combination of 335 clubs, known as "organized baseball," has attained a monopsony, or "butyer's monopoly,"3 over the market for skilled baseball talent. Use of this monopsony leverage has enabled the combination to regulate player salaries, exclude

*The scope of this Comment is limited to restraints on competition in the purchase of baseball players' services and the selling of professional baseball exhibitions. Because of space limitations, the industry's antitrust problems regarding radio and television will not here be discussed. At the behest of the Department of Justice, the major leagues rescinded agreements restricting competition in the sale of radio and television rights, October 8, 1951. Hearings before Subcommittee on Study of Monopoly Power of the Committee on the Judiciary, House of Representatives, Scrial No. 1, Part 6, 82d Cong., 1st Sess. (1951) (hereinafter cited as Hearings), 1177-9. Organizcd bascball is, hawever, watching the pending government antitrust suit against professional football's television restraints, United States v. National Football League, No. 12808, E.D. Pan, with more than casual interest. N.Y. Times, Jan. 27, 1953, p. 30, col. 1.

The problems created by unrestricted competition in the purchase of players' services appear to be common to all professional team sports. Clubs in professional football, professional basketball, and professional hockey have all patterned their practices in this market after organized baseball. Hearings, 1454-71, 1504-5; Topkis, Monopoly in Professional Sports, 58 Yale L.J. 691, 695-705 (1949). Even British Association Football (soccer), with a totally different heritage from American professional team sports, hats evolved trade agreements foreclosing competition for players' services. Sce MIINISTNY of Labour and National Service, Report of a Committee of Investigation into a Difference Regarding the Terms and Conditions of Assoctation Footband Playeus (1952).

The article by Topkis represents the severest indictment of the "bascball trust." The leading defense of organized baseball is Eckler, Baseball-Sport or Commerce?, 17 U. of CEI. L. Rev. 56 (1949). See also Neville, Baseball and the Antitrust Lanes, 16 Foro L. Rev. 208 (1947) ; and Notes, 53 Col. L. Rev. 243 (1953), 5 Intraniural L. Rev. (N.Y.U.) 206 (1950), 24 Notre Daure Law. 372 (1949), 32 VA. L. REv. 1164 (1946), 46 Yale L.J. 1386 (1937). On baseball player contracts generally, sec The Lane of Bascball, 113 N.Y.L.J. 1832, 1848, 1864, 1880 (1945); Johnson, Bascball and the Latu, 73 U.S.L. Rev. 252 (1939); Stratton, Baseball Jurisprudence, 44 Ass. L. REv. 374 (1910).

1. 15 U.S.C. $\S \S 1-3(1946)$.

2. Fashion Originators' Guild v. FTC, 312 U.S. 457, 465 (1941); National Cotton Oil Co. v. Texas, 197 U.S. 115, 129 (1905). See also Northern Securities Co. v. United States, 193 U.S. 197, 331 (1904).

3. "Monopoly" literally means one seller, or a number of sellers acting in unison, in a particular market. "Monopsony" was coined by economists twenty ycars ago to describe the reverse situation, when a single buyer or a number of buycrs acting in unison control the entire demand for a service or commodity, or enough of it to augment profits by restricting the amount purchased or by reducing the price paid. Wncox, 
competitors, and divide consumer markets among the member clubs. Today organized baseball is undisputed master over the entire professional sport wherever it is played in North America.

Organized baseball's dominion has seldom been challenged in the courts." In 1922 the Supreme Court immunized the industry from antitrust attacl: when Justice Holmes declared in the Fcdiral Rasiball case that the business of exhibiting baseball games was not interstate commerce and hence not subject to the Sherman Act. ${ }^{5}$ However, in the past four years, organized baseball's privileged position has been severely jolted, both in the courts and in Congress. Treble damage actions by three blaclilisted players in 1949 threatened to undermine the Federal Bascball case, on the basis of a concept

Conpetition and Monofoly in Angrican Industry 9-11 (TNEC Monograph 21, 1940).

"Zionopoly," as the term is employed in the Sherman Act, is defincd $c 0$ as to includs control over either the buyers' or sellers' side of the markit. Mandeville Island Farms, Inc. v. American Crystal Sugar Co, 334 U.S. 219, 236 (194S); Standard Oil Co. v. United States, 221 U.S. 1, 51-61 (1910). "Trade necessarily involves both buying and selling and the control and domination of either monopolizes trade." Miontrose Lumber Co. v. United States, 124 F.2d 573, 578 (10th Cir. 1941). Sec also Hood Rubter Co. v. United States Rubber Co., 229 Fed. 583, 587, 588 (D. Mass. 1916). Because monopoly also means merely control over supply and the commonest manifestation of markct domination is the power of sellers to raise price. there have been loose dicta in a few antitrust cases which might be interpreted to mean that monogoly gta monopoly is the only cvil which the Sherman Act was intended to reach. Arex Hosiery Co. v. Leader, 310 U.S. $469,500-01$ (1940). This overlooks the fact that monopsony power exercied by a buyer to stppress the prices of goods and services causes as much public harm as monopoly power. It would be anomalous to assert that the benefits of free competition are for buyers only. Fortunately, actual holdings by the Supreme Court indicate that monopsonistic restraints on competition are as illegal as monopolistic ones. Sce, c.g., Swiit \& Co. v. United States, 196 U.S. 375 (1905) ; Eastern States Rutail Lumber Ass'n v. United States, 234 U.S. 600 (1914); Anderson v. Shipownurs' Ass'n of Pacific Coast, 273 U.S. 35:9 (1926) ; United States v. Griffth, 334 U.S. 100 (1948); Schine Chain Theatres v. United States, $33+$ U.S. 110 (1948); Mandeville Island Farms, Inc. v. American Crystal Sugar Co., 334 U.S. 219 (1948); United States v. Great Atlantic \& Pacific Tea Co., 173 F2d 79 (7th Cir. 1949). The use of the cconomists' term, "monopsony," to deseribe "buyer's monopolies," it is suggested, might help clarify analysis of two quite different marleet phenomena. For this reason, this Comment will attemgt to use both terms according to their proper economic meaning.

4. Prior to Gardella v. Chandler, 172 F.2d 402 (2d Cir. 1949), only two antitrust actions had been brought against organized baccball. The first, Federal League of Professional Baseball Clubs v. National League, No. 373, N.D. Ill. (1915), was settled out of court. H.R. REP. 2002, \$2d Cong., 2d Sess. 56-7 (1952) (hereinafter eited as House Reporr). The second, Federal Baseball Club of Baltimore, Ine. y. National League, went to the Supreme Court. 259 U.S. 200 (1922), affirming 209 Fed. (US1 (D.C. Cir. 1920). The Department of Justice twice refused to bring suit under the Sherman Aet on behalf of the Government. N.Y. Times, Jan. 11, 1916, p. 12, col. 1; N.Y. Times, April 15,1937 , p. 25 , col. 2.

5. Federal Baseball Club of Baltimore, Inc. v. Sational League, $25 y$ U.S. 200 (1922), affirning 269 Fed. 681 (D.C. Cir., 1920); nuted in 34 H.uss. L. IRsv. 559 (1921). 
of commerce which the Supreme Court had radically changed since 1922. Out-of-court settlements temporarily averted the showdown, ${ }^{7}$ but once again the combination is plagued with antitrust suits by dissident players and club owners. $^{8}$

This renewed litigation prompted the House Antitrust Subcommittee to investigate the sport. ${ }^{9}$ Public guardians of free competition and private admirers of the national pastime, the Subcommittee hoped to find means of softening the clash between the Sherman Act and the industry's long-established trade practices. Spokesmen for organized baseball urged complete exemption equivalent to that established by judicial fiat in $1922 .^{10}$ But the

6. The leading case was Gardella v. Chandler, 172 F.2d 402 (2d Cir, 1949), reversing 79 F. Supp. 260 (S.D.N.Y. 1948), which ruled, on a motion to dismiss, that Gardella, a blacklisted "reserve jumper," stated a cause of action for treble damages under the Sherman Act. See also Gardella v. Chandler, 174 F.2d 919 (2d Cir. 1949), affirning CCH TRADE CAS. $\| 62,412$ (S.D.N.Y. 1949) (injunction pendente lite ordering reinstatement denied). The other two actions were by "contract jumpers," Max Lanier and Fred Martin of the St. Louis Cardinals. See Martin v. National League, 174 F.2d 917 (2d Cir. 1949), affirming Martin v. Chandler, CCH Trade Cas. $\Uparrow 62,397$ (S.D.N.Y. 1949); Martin v. Chandler, 85 F. Supp. 131 (S.D.N.Y. 1949). The Gardclla case is noted in 18 U. of Cin. L. Rev. 203 (1949), 34 Iowa L. Rev. 545 (1949), 33 MinN. L. Rev. 428 (1949), 37 Geo. L.J. 618 (1949), 62 Harv. L. Rev. 1240 (1949), 28 NEd. L. Rev. 616 (1949), 47 Micr. L. Rev. 1214 (1949), 20 TENN. L. Rev. 770 (1949), and 44 ILL. L. REV. 493 (1949).

7. After three trips to the court of appeals, organized baseball settled with all three players. House REPORT, 84. The amount of the settlements was not made public. However, it is known that the legal and litigation expenses of the Commissioner, American League, and National League amounted to $\$ 55,550$ in $1948, \$ 337,600$ in 1949 , and $\$ 93,400$ in 1950, indicating that the burden of these cases on organized baseball was not insubstantial. Hearungs, 332, 335, 1336, 1338, 1339, 1427. Senator A. B. Chandler, former Commissioner of Baseball, testified to the Antitrust Subcommittee: "I do not think the lawyers thought we could win the Gardella case." Hearings, 290.

8. See notes 163-5 infra.

9. N.Y. Times, May 5, 1951, p. 21, col. 6; N.Y. Times, May 11, 1951, p. 34, col. 2; Washington Star, May 20, 1951, pp. 1, 5. See also opening statement of Rep. Celler (N.Y.), Chairman of the Subcommittee. Hearings, 1-4. Originally known as the Subcommittee on the Study of Monopoly Power, the Subcommittee was renamed the Antitrust Subcommittee during the reorganization of the House Judiciary Committee in 1952. Similar Congressional investigations had been proposed in prior years. In 1913 Rep. Gallagher (IIl.) introduced a resolution to investigate the "Baseball Trust." H. REs. 64, 63d Cong., 1st Sess., 50 Cong. Rec. 323; and in 1937 Rep. Ray Cannon (Wis.) proposed an investigation of the "existing baseball monopoly." H. REs. 204, 75th Cong., 1st Sess., 81 Cong. Rec. 4186. Both resolutions died in the Rules Committee.

10. Senator Edwin Johnson (Colo.), president of the Western League, sounded tha call to arms in a syndicated newspaper article, in which he said: "Player contracts, including the much-misunderstood reserve clause, can be and must be legalized. . . . It is getting so that every little pipsqueak troublemaker and every disgruntled ballplayer nowadays attacks the reserve clause to lend support to his pet peeve. These annoyers are quick to indulge in legal blackmail to extract cash and other valuable consideration from the game which do not rightfully belong to them." N.Y. Times, April 22, 1951, $\S 5$, p. 5, col. 6 (city edition). But, compare Johnson's remarks made two years later, 
committee, not satisfied that organized baseball merited the brosd immunity it desired, passed back to the courts the burden of resolving the conflict between the national policy of economic competition and the intricate pattern of restrictive practices which constitute the present economic basis of professional baseball. ${ }^{11}$

Organized baseball relies on three lines of defense to preserve its existing hegemony. If possible it hopes to prevail in the jurisdictional argument founded on the Federal Baseball decision. ${ }^{12}$ Failing this, it asserts that monopsonistic restraints in the personal service market are not within the prohibition of the Sherman Act. ${ }^{13}$ And, finally, it claims its restrictions are reasonable in the light of the peculiar economic conditions prevailing in professional sports. ${ }^{14}$ The extensive hearings and detailed report of the House Antitrust Subcommittee provide for the first time an adequate factual basis for evaluating these legal defenses and for exploring possibilities of remedial action. $^{15}$

infra note 269. On May 23, 1951, three identical bills, H.R. 4229, 4230, and 4231, were introduced in the House of Representatives, which would totally exempt all "organized professional sports enterprises" from the antitrust bills. 97 Co:ic. Rec. 5763 (1951). Senator Johnson himself introduced a similar bill, S. 1526, in the Senate. 97 Co:sG. Rae. 5663 (1951). Rep. Herlong (Fla.), proponent of one of the three House bills, formerly was president of the Florida State League in organized bascball. HEarsucs, 443.

11. House Report, 22S-32. Quipped sports columnist Red Smith: "After ten long arduous months, the status has tottered triumphantly back to quo." N.Y. Herald Tribune, May 23, 1952, p. 20, col. 5 .

12. Brief for Appellees, pp. 10-42, Toolson v. New Yorl: Yankees, Inc, 200 F.2d 198 (9th Cir. 1952) ; Brief for Appellees, pp. 10-35, Corbett v. Chandler, 6th Cir., Feb. 20, 1953; Brief for Appellees, pp. 14-32, Kowalski v. Chandler, 6th Cir., Feb. 20, 1953.

13. Brief for Appellees, pp. 43-63, Toolson v. New York Yanlsees, Inc, 200 F.2d 193 (9th Cir. 1952) ; Brief for Appellees, pp. 35-9, Corbett v. Chandler, 6th Cir., Feb. 20, 1953; Brief for Appellees, pp. 21-6, 39-47, 6th Cir., Feb. 20, 1953.

14. "Organized baseball, represented by eminent counsel, has assured the sutcommittee that the legality of the reserve clause will be tested by the rule of reason." House REPORT, 231. See also testimony of Commissioner Frick, Hearnias, 34; Eclser, Bascball -Sport or Commerce?, 17 U. of CHx. L. Rev. 56, 6S-71 (1949).

15. The 1643-page committee hearings represents the most exhaustive source of information on organized baseball's operations, and its 232-page report the most thorough analysis of the combination's trade practices.

Prior to the congressional investigation of organized baseball, few sources on the history and economics of the trade combination vere available. The most detailed works were student theses. See Craig, Ofganized Bastball: Ari Industry Study $0 z$ a $\$ 100$ Millyon Spectator Sport (unpublished thesis in Oberlin College Library, 1950); and ARMsTROAG, THe Unionization of Basebnli (unpublished thesis in Princeton University Library, 1947). Of the many popularized histories of organized baseball, the most useful are: Lieb, Basebali Story (1950); Aller, 100 Years of Basedall (1950); R. 34. Simte, Baserall (1947); Richter, History and Recosds of Baserall (1914); Sparding, Azrerica's National Gajre (1911); and Palimer, Athletic Sromss in Airenica (1899). For collections of club and player statistics, see Tunfun Asd Tzorspson,

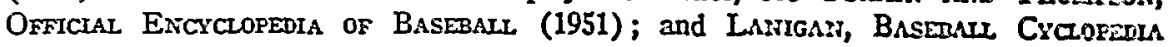




\section{Organization and Economic Practicts of Organized Baseball}

Professional baseball ranks high in public favor among spectator amusement industries. In 1950,52 million persons ${ }^{16}$ paid 68 million dollars ${ }^{17}$ to watch 382 clubs $^{18}$ in organized basball play 30,000 games. Gross sales for these clubs reached 82 million clollars, including 54 million net gate receipts, 20 million from concession sales, and 4 million from radio and television. ${ }^{10}$ The 54 million dollars realized by the industry-wide combination at the box office exceeded all other professional team sports combined. ${ }^{20}$ The combination employed 8,000 professional players, ${ }^{21}$ who were paid between $\$ 80$ and $\$ 16,000$ a month for their services. ${ }^{22}$

But professional baseball is more than a business; it is also a sport. Unlike firms in other industries, a professional sport enterprise must cooperate with chosen competitors in order to create a marketable product. Because the attractiveness of each product or exhibition depends on its uncertainty and dramatic value, this cooperation must extend beyond the mere performance of the exhibition to the creation of common trade practices which promote equality of playing skill among opposing clubs. Furthermore, in the baseball industry the sole incentive for business decisions is not the profit motive. Many club owners look upon their investments as a diverting, and sometimes costly, hobby. The rewards they seek are not profits but pennants, pleasure, and prestige. ${ }^{23}$

(1922). On current matters in organized baseball, see the trade newspaper, The Sporting News, published weekly, and its annual record books: THe BASEanLl. Register (statistics on major league players' careers) and the OFFictal BASEBALL Guide (club and player records). The trade regulations of organized baseball appear in the BASEDALt BLUe Boors, published annually by the Heilbroner Baseball Bureau, at Ft. Wayne, Ind.

16. Hearings, 1616. Paid attendance in organized baseball rose from a low of $12,600,000$ in 1933 to an all-time peak of $62,380,000$ in 1949 . Since that time there has been a steady recession, due perhaps to the inroads of television and the loss of player talent to the armed forces. In 1952 paid attendance was 40,300,000. NatronsL Ass'N of Prof'c Baseball Leagues, 1952 Highlights 1-2 (1952); Sporting News, Dec. 17, 1952, p. 13, col. 3; 1953 Worrd Almanac 806, 809.

17. House REPORT, 86. The estimate used includes 20 percent federal excise tax and miscellaneous state and local excise taxes.

18. Id. at 12 .

19. Id. at 86 .

20. Dep't of Commerce, National Inconge Supplement to Survey of Current Business 197 (1951); Hearings, 963.

21. HOUSE REPORT, 12-13.

22. Hearings, 965 . The salary figures are for 1951, but they probably approximate 1950 levels. The highest player salary was $\$ 90,000$ for a $5 \frac{1}{2}$ month playing scason, a stipend received by both Joe DiMaggio and Ted Williams. See N.Y. Herald Tribune, Oct. 23, 1951, p. 30, col. 6 .

23. This is not to say that professional baseball may not be a lucrative investment for some. Net profits for the sixteen major league clubs combined averaged four million dollars (thirteen percent of gross sales) annually from 1946 to 1949. HedresNGs, 1636. However, only six of the sixteen largest investors in major league clubs, and 291 


\section{League Organization}

Professional baseball was still a toddling infant when its promoters discovered that the sport was most successful when clubs were associated in leagues. To meet monthly payrolls, club owners sought assurances of a minimum number of games. In addition, they discovered that established rivalries with other clubs for the pursuit of mythical "championships" enhanced daily attendance. As a consequence, clubs affiliated into voluntary" unincorporated associations or "leagues" with prearranged playing schedules, and awarded a pennant to each season's champion. ${ }^{24}$ Through trial and error, eight clubs were found to be the most workable size for a league. More clubs left too many members out of the running for the pennant, and fewer produced monotony of opposition. ${ }^{25}$

Dominating organized baseball are sixteen "major league" clubs, equally divided between the American and National leagues. In 1950 they realized almost half of the industry's $\$ 2$ million dollars worth of sales. ${ }^{20}$ The eight members of each league are parties to a league constitution which prescribes the methods for drawing up the playing schedule, transferring players, and dividing gate receipts. ${ }^{27}$ The American and National leagues, in turn, are allied under the Major League Agreement and Major League Rules, which establish the office of Commissioner of Baseball and further regulate the member clubs' activities, particularly as to the acquisition and control of players. ${ }^{29}$ Representatives of the 16 clubs meet periodically to amend their league constitutions, the Major League Agreement, and the Miajor League Rules.9

out of 2,287 officers and directors of minor league clubs, in 1951 depended on baseball for a living. House REPORT, 91. The New York Yankees, the most profitable enterprise in the industry, has distributed only eight percent of its profits to its owners since 1920, and Tom Yawkey, owner of the Boston Red Sox since 1933, has lost $\$ 2,000,000$ on his baseball investment. Hearings, 1599-1601. See also House Rerons, 92-7; Heanimgs, 1516-30, 1625, 1629-35.

24. House Report, 17-20; Hearraus, 1509-14.

25. The National League, organized in $187 \%$, had six members in 1877 and 1878 , twelve members from 1892 to 1899 . In neither period were the playing seasons profitable. HouSE REPORT, 20,37. Eight clubs per league have heen the standard throughout organized baseball since 1900. In 1952 all thirty-one of the minor leagues commencing the season with eight clubs finished intact. Two of the eleven leagues starting with si: clubs and the one league which started with ten clubs lost one or more of their members before the season ended. National Assocration of Professionis Baserill Leagues, 1952 HignLIGHTS passinn (1952).

26. HousE REPORT, 86 .

27. Hearings, 1095-1111 (National League Constitution); 1111-21 (Ameriean Leagus Constitution) ; 1406-10 (American League reorganization agreement, 1934).

28. Hearings, 1121-5 (Major League Agreement, 1940); 1125-54 (MIajor League Rules); 1176-9, 1186-7 (October and December, 1951, amendments to Major League Rules).

29. National League Constitution, $\$ \$ 60,68$, Hewninos, 1109, 1111 ; American Leaguc Constitution, arts. IX, XVI, Hearings, 1115, 1110; Major League Agrcement, art. V*, Heatings, 1124; Major League Rule 27, Heirnngs, 1148. 
Between such meetings, major league affairs are supervised by elected leagtue officers and the Commissioner with the aid of the Excutive Council, a quasiboard of directors composed of four major league club presidents. ${ }^{30}$

Forty-three "minor leagues," graded in seven classifications ${ }^{31}$ according to the size of their consumer markets, ${ }^{32}$ are parties to the National Association Agreement. ${ }^{33}$ These leagues include 319 clubs located in forty-four different states and three foreign countries. ${ }^{34}$ Binding the major and minor leagues together is the Major-Minor League Agreement with appended rules. ${ }^{\text {at }}$ By this agreement the minor leagues accept the jurisdiction of the Commissioner as final arbiter of all disputes and agree to uniform procedures regarding the making and transfer of player contracts.

Minor leagues sought and gained admission to organized baseball becatuse of the mutual benefit derived from the combination's agreement not to compete for players' services. Because admission depended on the recognition of existing members' local market monopolies, new minor leagues tended to stake their franchises in the largest cities not then represented in organized baseball. Hence the older leagues not only tend to be located in the more populous markets, but also possess the higher classifications in the combination's hierarchy ${ }^{36}$ with resultant priorities in the market for player contracts. ${ }^{37}$

30. National League Constitution, $\$ \S 15-31$, HeArungs, 1098-1101; American Leaguc Constitution, arts. VI-VIII, Hesrings, 1113-5; Major League Agreement, arts. I, II, Hearings, 1121-4; Major League Rules 26, Hearings, 1147-8.

31. A complete directory of minor leagues, clubs, and executives is published annually in Heilbroner Baseball Bureau, Baseball Blue Book. In 1952 there was one league (Pacific Coast League) in the "Open" classification at the top of the minor league hierarchy; two leagues in "AAA"; two in "AA"; four in "A"; eight in "B"; clcvell in "C"; and fifteen in "D."

32. National Association Agreement, § $10.02(\mathrm{~b})$, Heakings, 1195.

33. Henrings, 1182-5, 1187-1247.

34. 324 minor league clubs were in business at the start of the 1952 playing season, Sporting News, April 16, 1952, pp. 28-29; but five small clubs in the Class D leagues were unable to complete their schedule commitments. National Associstion of Professtonal Basebali Leagues, 1952 Highlights passim (1952). The foreign countries represented in organized baseball are Canada, Cuba, and Mexico.

35. Hearings, 1154-7 (Major-Minor League Agreement, 1946); 1157-76 (MajorMinor League Rules) ; 1177, 1179-80 (1951-52 amendments to Major-Minor League Agrcement) ; 1177, 1180-2 (1951-52 amendments to Major-Minor League Rules). The 1951-52 amendments pertained to the creation of a new "Open" classification for the Pacific Const League, which long has aspired to major league status. Sporting News, Nov. 7, 1951, p. 2 , col. 1 ; Nov. 21,1951 , p. 13, col. 1 .

36. Boston and Chicago were charter members of the National League when it was first organized in 1876. The present New York and Philadelphia clubs joined in 1883, Pittsburgh in 1887 (after five years in the old American Association), Cincinnati in 1890 (after eight years in the old A.A.), Brooklyn in 1890 (after six years in the old A.A.), and St. Louis in 1892 (after ten years in the old A.A.). Turkin \& Thompson, Orficinl BAsEBaII ENCYCLOPEDIA 402-05 (1951). The American League, which dates back to 1886 as a minor league, forced its way to major league status in 1901-03, retaining one old nember (Detroit), placing five clubs in cities occupied by the National League 
Although allegedly independent from the major leagues, the minor leagues are largely controlled by their big league brothers. Miore than half of the minor league clubs are either direct subsidiaries to major league corporations or affiliated through "working agreements." commonly instruct these minor league affiliates how to vote at their annual National Association meetings. ${ }^{39}$

Also associated with the National Association are four "unclassified affiliates"-winter leagues in Cuba, Puerto Rico, Panama, and Venezuela." The only independent professional leagues in North America which are not parties to the Major-Minor League Agreement are the Negro American League, the Mexican League, the Mexican Pacific Coast League, and the Veracruz Winter League. The first two have understandings with organized baseball not to compete for its players in return for similar hands-off guarantees:41 and the others are remote winter leagues which as yet have offered little threat to organized baseball's restrictive trade practices. 12

Governing this combination of professional baseball clubs are the club presidents, who determine the industry's trade practices ; forty-five league presidents, who administer league affairs at the sufferance of the club owners; and the Commissioner of Baseball and the President of the National Association, who handle inter-league affairs. Ford C. Frick, the present Commissioner, possesses broad investigative and judicial power. He is authorized to investigate any acts or practices "alleged or suspected to be detrimental to the best interests of the national game of baseball" and to determine what "preventive,

(Boston, Chicago, New York, Philadelphia, and St. Louis), and invading two cities which had been abandoned by the National League when it cut its circuit from twelve clubs to eight in 1900 (Cleveland and Washington). Id. at 395-6. Of the five largest minor leagues (Class "AA" and higher), the International League (occupying secondary cities in the northeast and the two largest Canadian cities) dates bacls to 18S4, the Southern Association to 1885, the Texas League to 188S, the American Association (occupying secondary cities in the mid-west) to 1902, and the Pacific Coast League to 1903. All other minor leagues presently operating entered the combination since World War I. Directory of Minoz League Clubs and Leagues (unpublished, Sporting News, 1949).

37. See page 595 infra.

38. House Repost, 188; Sporting News, April 16, 1952, pp. $28-9$.

39. Hearings, 76S-9.

40. House Report, 81 ; Hearings, 233-9.

41. Hodse Report, 82, 85; Hearings, 1295, 1548-50. The Negro American League reduced its membership from eight clubs to six in 1952, Sporting News, Jan. 9, 1952, p. 19 , col. 4 , and the Mexican League also operated with six clubs. Sporting Niews, Oct. 8,1952 , p. 29, col. 3. The Mexican League apparently wishes to keep its nominal independence. Said President Eduardo Q. Pitman, in February, 1952: "The feeling of all league and club executives at this time is unanimous that we will not join Organized Ball since we are proud of our independence. This does not mean, of course, that we are not ready for friendly agreements and pacts with Organized Ball." Sporting News, Feb. 20, 1952 , p. 28 , col. 3 .

42. Sporting News, Aug. 20, 1952, p. 38, col. 2. 
remedial or punitive action is appropriate in the premises."43 Appropriate action may consist of a public reprimand, ${ }^{44}$ fine, ${ }^{45}$ probation, ${ }^{40}$ temporary suspension, ${ }^{47}$ or permanent blacklisting. ${ }^{48}$ In addition, he keeps careful tab on each major league player and may discipline those who fail to abide by the leagues' monopsonistic player agreements. ${ }^{49}$ George M. Trautman, president of the National Association, exercises similar functions for the minor leagues. ${ }^{60}$

43. Major League Agreement, art. I, HenRINGS, 1121-2.

44. Judge Kenesaw Mountain Landis, Commissioner I, publicly castigated a group of major league players in 1927 for contributing money to a rival club as a reward for defeating a pennant contender, conduct which he described as "an act of impropricty, reprehensible and censurable, but not corrupt." SPINK, JUDGE LANDIS AND TWENTY-FIVE YEARS OF BASEBALI 171 (1947).

45. Senator A. B. Chandler, Commissioner II, levied forty-one fines on clubs or their employees from 1946 to 1950 for various infractions of the combination's rules or conduct "detrimental to baseball." Hearings, 340-1.

46. Ford Frick, Commissioner III, placed outfielder Jim Rivera on a year's "probation" for "moral delinquency" shortly after the player was exonerated from a rape charge by a Chicago grand jury. N.Y. Times, Nov. 13, 1952, p. 39, col. 2. "It is no secret that if Frick ... had not been warned by his lawyers that to throw Rivera out of baseball would invite a suit, the outfielder would have been given the heave-ho." Sporting News, Nov. 19, 1952, p. 1, col. 1.

47. Chandier suspended Leo Durocher from organized baseball for the 1947 season because of an accumulation of alleged improprieties. N.Y. Times, April 10, 1947, p. 1, col. 6.

48. One of the first acts of Judge Landis as Commissioner was to blacklist permanently eight players of the Chicago White Sox who were alleged to be involved in the "Black Sox scandal"-the "throwing" of the 1919 World Series to Cincinnati. N.Y. Times, Mar. 13, 1921, p. 16, col. 1; House REpoRT, 60. One of his last acts was to force out a major league club owner for gambling on his club's games. N.Y. Times, Nov. 24, 1943 , p. 24 , col. 1 .

49. The most famous example in recent years was the five-year blacklisting sentence imposed on eighteen major league players who spurned the clubs "owning" their contracts to play in the Mexican League in 1946. House REPORT, 77-84; HeARINas, 1303. After three years and the filing of three antitrust suits, Chandler "tempered justice with mercy" and reinstated the "jumpers." Hearings, 1587-8. In 1949 Chandler fincd the New York Giants $\$ 2,000$ and Manager Leo Durocher $\$ 500$ for the latter's offer of employment to Coach Fred Fitzsimmons of the Boston Braves. Fitzsimmons was also fined $\$ 500$ and suspended one month for assuming, contrary to organized baseball's rules, that he could sell his services in a free market. HeArINGs, 305-06. For other illustrative decisions by the Commissioner of Baseball enforcing the monopsonistic agreements of organized baseball, see Hearungs, 222-3, 311-12, 317-23, 627-87.

50. National Association Agreement, $\S \S 6,15.08-15.14,16.02$, 19, 21, HEArrngs, $1191-$ 3, 1204-5, 1207, 1210-4. George M. Trautman, president of the National Association, permanently banished a minor league player for his implication in the University of Kentucky basketball scandals. N.Y. Times, Sept. 24, 1952, p. 15, col. 5. Trautman's predecessor, in 1943, ordered forfeiture of games played by Hartford (Eastern League) as punishment for the employment of a blacklisted player. N.Y. Times, June 30, 1943, p. 26, col. 8. For illustrative examples of decisions by the minor league president, sce HeARings, 1443-53. 
The only appeal from the decisions of these industry czars is to the courts, a step which few have ventured to take. ${ }^{51}$

\section{Monopsony in the Player Market}

At the foundation of organized baseball's trade practices is the "reserve rule," an agreement not to compete for players' services. By a time-honored system for division of the player market, each club in organized baseball is given exclusive right to bargain with its "reserved" players. By foreclosing market alternatives from the player, each club wields the economic power of the entire combination in determining the price it pays for its most important factor of production. The player, facing 335 clubs acting as one, must either accept the salary offered or leave his profession.

The present reserve rule, like many other baseball trade practices, represents a compromise between two conflicting motives. For the individual club. profits and intangible rewards are directly related to the playing success of the team. A club which wins 63 percent of its games tends to draw twice as many fans as it would winning 42 percent of its games and three times as many as it would winning 25 percent of its games. Each club, therefore, is desirous of employing the best players it can find.52

If left unchecked, however, the individual club's pursuit of the best player talent will tend to destroy first the club's competitors and ultimately the club itself. Only one club in a league can win the pennant, and unless the losers can also prosper, the victor of one year may become bankrupt the next through lack of opponents to play. Collective financial success for a league requires continued equality of competition on the playing field. Aside from fluctuations due to the business cycle, the collective profits of competing clubs within the same league are directly related to the closeness of the pennant race. Analysis of the major leagues since 1920 indicates that at any given level of national prosperity, a lezgue derives 50 percent more gate receipts if the pennant-winning club averages .575 in won and lost percentage than if it averages .750. Such equality among league members is promoted by

51. Prior to the recent rash of treble damage actions, there vere only three appeals for legal redress from the decisions of the Commissioner or minor league president In Mrilwaukee American Ass'n v. Landis, 49 F.2d 298 (X.D. Ill. 1930) (injunetive relief denied to a major league club owner who had lost reserve rights to a player for his violation of the Miajor League Rules), the aggrieved party withdrew his appeal after Landis threatened to resign. House REPOST, 67. Other instances involved blacklisted players. Bennie Kauff, banned for life in 1921 for an alleged car theit, failed in his bid for reinstatement by court order. Kauff v. National Exhibition Co., No. 2269, N.Y. Sup. Ct., N.Y. County, Jan. 17, 1922. Two of the "Black Sox" (sce note 48 suspro) failed in their bid to recover damages on a common law conspiracy charge. Felsch v. American League Baseball Club of Chicago, Inc. and Risberg v. Amerian League Baseball Club of Chicago, Inc., Cir. Ct., Milwaukee, Wis., May 12, 1923.

52. House Report, 103-104; Hearings, 1593. 
trade practices which make it possible for each club to hire teams of relatively equal ability. ${ }^{53}$

From the inception of professional baseball in 1864 until 1879 , players were free to sign with whomever they pleased. Because a single club's success depended upon its players' abilities, the bidding for talent was intense. "Revolving," or transferring from club to club for a higher salary, became such a common practice that most of the star performers gravitated to the wealthiest clubs. Competition on the ball field became a farce. In 1869 the Cincinnati Red Stockings played 57 games without a defeat. In 1875 the Boston Red Stockings won the professional championship with 71 victories and only 8 losses. Their nearest competitor, the Philadelphia Athletics, won 53 games and lost 20. The last-place Brooklyn Atlantics won only 2 games and lost 42.54

Due to this unbridled competition for players' services, player salaries accounted for two-thirds of the average club's expenses, and no club could report any profits to its stockholders. Of twenty-five clubs which competed in the first professional league, 1871-75, sixteen were financial failures. Eight of the nine survivors reorganized into the National League in 1876, but prospects for the young industry failed to improve. Again no club made money. Of the fifteen clubs admitted to membership in the first four years, eight folded by the end of the 1879 season. 55 In a desperate attempt to avert financial ruin, the seven survivors voted secretly to permit each club to "reserve" five of its players for the 1880 season. The league members agreed not to compete for the services of any reserved player. ${ }^{50}$ The new rule not only enabled clubs to reduce their payrolls but also brought more equal playing competition and consequent increases in gate receipts. Each year from 1881 until 1890, at least five National League members made money, and the mortality rate of clubs sharply declined.57

The reserve rule agreement did not come out into the open until 1883, when the National League entered a "National Agreement" with its strongest rival, the old American Association. This agreement, which marked the formal beginning of organized baseball, set up a board of arbitration to govern the sport, permitted each club to reserve a full team (nine players and two substitutes), and authorized fines for any club failing to honor reserve lists or player contracts. ${ }^{58}$ The last link in this monopsonistic agreement was added a few years later when the clubs agreed to make player contracts and reservation rights assignable within organized baseball, thus reducing players to quasi-chattels who could be bought, sold, or bartered. ${ }^{50}$

\footnotetext{
53. HOUSE REPORT, 104-105.

54. Id. at 17-22.

55. Id. at 18-22.

56. Id. at $22,111$.

57. Id. at 23-5; Turkin \& Thompson, Offictal Basebali Encyclopedia 402.04 (1951).

58. Hearings, 141-3, House Report, 26-7.

59. House REPORT, 29-31. While the transfer of this right is commonly referred to as the sale of a player or player contract, actually it is merely the transfer of the
} 
As originally formulated, the reserve rule carried no sanctions against players who chose to ignore reservation claims. Although the owners' agreement barred such players from obtaining employment elsewhere in organized baseball, they were free to seek more remunerative employment among the many independent professional clubs without foreclosing a later return to their reserving club if they desired. ${ }^{00}$

The clubs in organized baseball quickly realized the potentialities of the reserve rule. Having agreed among themselves not to compete for each other's players, they sought to expand their monopsony power throughout the entire baseball industry. They blacklisted players who were lured to the free marliet and boycotted independent clubs or leagues until such outlaws were forced out of business or joined the combination as "minor leagues." 61

Against well-financed leagues, however, the blaclilist and boycott proved to be ineffective to halt the exodus of players offered higher salaries. ${ }^{62}$ To remedy this situation, organized baseball sought the aid of courts of equity.

exclusive right to employ a player. Because each player is obliged to sign a contract granting the club the rights to reserve him for the succeeding year and to assign his services elsewhere in organized baseball (Hearmes, 1249-52, 1255-7), these sales, for convenience, are here referred to as the sale of player contracts in the colloquial sense.

Despite the promises of the player in the uniform contract, courts have bren reluctant to interpret transfers as obligating the player to report to the transferee club, because of the constitutional prohibition of involuntary servitude. The consideration for transfer payments is the mere promise of the transferor club to release the player. Augusta Baseball Ass'n v. Thomasville Baseball Club, 147 Ga. 201, 93 S.E. 208 (1917); Armour v. American Base Ball and Athletic Exhibition Co. of St. Louis, C.P., Cincinnati, Ohio, June 27, 1902, Philadelphia Public Ledger, June 28,1902, p. 20, col. 7. The player's refusal to report to the purchasing club does not constitute a breach of the contract to sell. Toledo Base Ball Co. v. von der Ahe, No. 4339, C.C.N.D. Ohio, Feb. 24, 18S5. Cf. Macon Baset.all Ass'n, Inc. v. Pennington, 45 Ga. App. 611, 166 S.E. 35 (1932). Agreements for the sale of player contracts have never been contested as being void in restraint of trade.

Recalcitrant players, effectively assigned by "baseball law;" have been uniformly successful in recovering damages for breach of contract from the transferor club, both when they refused to accept the assignment, Griffin v. Brooklyn Ball Club, 68 App. Div. 565, 73 N.Y. Supp. S64 (4th Dep't 1902) ; Kelly v. St. Paul Baseball Club, No. 92841, Minn. Dist. Ct., St. Paul, Minn., May 23, 1906; Kinney v. Newark Federal League Ball Club, Ine., No. 21225-1916, N.Y. Sup. Ct, Oct. 16, 1917; and when they reported to the assignee 166 App. Div. 484, 151 N.Y. Supp. 557 (1st Dep't 1915), aff'd, 221 N.Y. 704, 117 N.E. 1051 (1917) ; George v. Kansas City American Ass'n Baseball Co., 219 S.W. 134 (Mo. App. 1920); Hofman v. Chicago League Ball Club, 195 Ill. App. 249 (1915). The effectiveness of transfers of the exclusive right to employ players stems, therefore, not from enforcement by civil courts but from the blacklisting sanctions of organized baseball.

Player contracts have been transferred for twenty-five cents, Reach Base Ball Guide, 1907 , p. 470 ; for $\$ 250,000$, Sporting News, June 25, 1952, p. 4, cols. 3, 4, N.Y. Times, Oct. 27, 1934, p. 10, col. 1; for a bulldog, N.Y. Times, Jan. 12, 1915, p. 10, col. 3; for a bird dog, ibid; for a turkey, Sporting News, Nov. 12, 1952, p. 11, col. 3; and for an airplane, N.Y. Times, Dec. 3, 1924, p. 17, col. 2.

60. 1883 National Agreement, $\int 5$; Hearriges, 142; Horse. Refust, 34.

61. See, e.g., the account of the 1834 Union Association war. Hovse Reporr, 27-3.

62. See, e.g., the account of the 1890 Players League War. House Reroms, 33. 
Beginning in 1887, every player's contract in organized baseball contained a "reserve clause," by which the player recognized the club's right to reserve him for the succeeding year. ${ }^{63}$ The club owners interpreted the reserve clause as a valid "option to renew" which would give legal sanction to their monopsonistic agreement. The courts, however, felt otherwise. ${ }^{64}$ Whenever clubs in organized baseball sought to restrain players from "violating" the reserve clause to play for an independent league, judges turned a deaf ear. During the Players' League War of 1890, state courts in both New York and Pennsylvania refused to restrain players from leaving their reserving clubs to join the new league, on the ground that the reserve clause was indefinite, lacking in mutuality, and unconscionable. ${ }^{65}$ The federal court in New York City denied injunctive relief on the ground that the reserve clause was nothing more than "a contract to make a contract if the parties can agree."

Attempts to tighten the reserve clause to meet judicial objections without sacrificing its features as an agreement not to compete for players' services ${ }^{\mathbf{6 7}}$

63. House REPORT, 31-3. The original "reserve clause" read:

"It is further understood and agreed that the said party of the first part shall have the right to reserve the said party of the second part for the season ensuing the term mentioned in paragraph 2, herein provided, and said right and privilege is hereby accorded the said party of the first part upon the following conditions, which are to be taken and construed as conditions precedent to the exercise of such extraordinary right or privilege, viz:

"I. That the said party of the second part shall not be reserved at a salary less than that mentioned in the twentieth paragraph herein except by consent of the party of the second part.

"II. That the said party of the second part, if he be reserved by the said party of the first part for the next ensuing season, shall be one of not more than fourteen players then under contract; that is, that the right of reservation be limited to that number of players and no more." Metropolitan Exhibition Co. v. Ward, 24 Abb. N.C. 393, 400, 9 N.Y. Supp. 779, 781-2 (Sup. Ct. 1890).

64. See cases cited notes 65,66 infra and House RePoRT, 33-4.

65. Metropolitan Exhibition Co. v. Ward, 24 Abb. N.C. 393, 9 N.Y. Supp. 779 (Sup. Ct. 1890) ; Philadelphia Ball Club, Ltd. v. Hallman, 8 Pa. County Ct. 57 (C.P. 1890). The complete uniform player's contract then used is reprinted in the Ward case, $24 \mathrm{Abb}$. N.C. at $395-401$.

66. Metropolitan Exhibition Co. v. Ewing, 42 Fed. 198, 204, 24 Abb. N.C. 419, 429 (C.C.S.D.N.Y. 1890).

67. "Amos Rusie, after leading the National League in strikeouts for six successive seasons and winning 24 games for New York in 1895, decided he deserved something better than a salary reduction from $\$ 3,500$ to $\$ 3,400$ in 1896 . He held out for the entirc season, believing that after a year his reserve clause would lapse and he would be eligible to sign with the highest bidder. When the New York Giants reserved him again in 1897, Rusie filed a suit in a New Jersey Federal court seeking $\$ 5,000$ damages and an unconditional release. The case was settled out of court." House REPORr, 36. Rusic v. National Exhibition Co., No. 3893, C.C.D.N.J., May 26, 1897. The experience of this suit and the Players League litigation prompted the National League to revise the reserve clause to provide for two or three one-year options to renew at a predetermined salary. Griffin $y$. Brooklyn Ball Club, 68 App. Div. 566, 569, 73 N.Y. Supp. 864, 866 (4th Dept. 1902); Philadelphia Ball Club v. Lajoie, 10 Pa. Dist. 309, 310 (C.P. 1901). This change was 
proved a failure. When the American League bolted organized baseball $i$ 1901, proclaimed itself a major league, and raided National League clubs fc reserved players, court actions failed to stop the stampede for higher salarie Pennsylvania enjoined three National League players from jumping the $r$ serve clause to play with the Philadelphia Athletics, ${ }^{\text {,s }}$ but two of the playes signed new contracts with the Cleveland American League club and Oh: refused to enforce the Pennsylvania decree. ${ }^{69}$ Missouri likewise refused 1 enforce this clause in equity, in part on the ground that the uniform player contract was made in furtherance of a combination in restraint of trade. ${ }^{70}$

Another element in organized baseball's monopsonistic agreement not 1 compete for players' services has been the attempted enforcement of playi contracts, as distinguished from the reservation right, during the term of suc

believed to provide sanctity in contract law for the agreement not to compete for playe services. In practice, however, players were required to sign new contracts containi identical renewal features before participating in more than five games of their secor year. Thus, players were as effectively bound to their reserving clubs as under the mo conventional reserve clause. Philadelphia Public Ledger, May 8, 1902, p. 16, col. 7.

68. Philadelphia Ball Club, Itd. v. Lajoie, No. 789, Philadelphia Ball Club, Ltd. Fraser, No. 790, Philadelphia Ball Club, Ltd. v. Bernhard, No. 791, C.P., Philadelphi Pa., April 28, 1902. These decrees were based on the State Supreme Court's decisi in Philadelphia Ball Club v. Lajoie, $202 \mathrm{~Pa} .210,51$ Atl. 973 (1902), reversing $10 \mathrm{~F}$ Dist. 309 (C.P. 1901). Lajoie, who had received a $\$ 2,400$ salary with the Phillies, receiv $\$ 5,500$ under his 1902 contract with the American League. Philadelphia Public Lodgr April 24, 1902, p. 16, col. 3.

69. Philadelphia Base Ball Club, Ltd. v. Lajoie, 13 Ohio Dec. 504 (C.P. 1902); Phil delphia Base Ball Club, Ltd. v. Bernhard, No. 79544, C.P., Cleveland, Ohio, Aug. 16, 190 Fraser voluntarily returned to the Phillies. Philadelphia Public Ledger, May 16, 1902, p. 1 col 6.

70. American Base Ball \& Athletic Exhibition Co. of St. Louis v. Wallace and Hei rick, Nos. 24647-A and 24648-A, St. Louis Cir. Ct, Mray 6, 1902, decided on the basis American Base Ball \& Athletic Exhibition Co. v. Harper, 54 CErrr. L.J. 449 (St. Lot Cir. Ct. 1902.) Defendants' attorney, John D. Johnson, in his final argument, April 29, $19 \mathrm{C}$ "called attention to the reserve rule, whereby the players are held for a club from ye to year, and stated that the National League violated the antitrust lav at least in spin when it dictated the salary of players and the admission to be charged to the games." : Louis Globe-Democrat, April 30,1902, p. 13, col. 4. The court denicd the injunctio on the grounds that the contracts (1) lacked mutuality; (2) were elements of a cor bination in violation of the Sherman Act; and (3) abrogated the players' constitution rights to follow their chosen occupation. Harper case, 54 Cenr. L.J. 449 (St. Louis Cir. C 1902), Philadelphia Public Ledger, May 7, 1902, p. 18, col. 3. In the Philadelph cases, counsel for player-defendants also charged that the National League constitutic rules, and regulations violated the Sherman Act "because every player who entered $t$ service of the National League was reduced to a condition of perpetual servitude, a that every member of the League has combined in an illegal contract in restraint trade." Philadelphia Public Ledger, April 29, 1902, p. 14, col. 3. Judge Ralston, howew rejected this contention and made the injunctions permanent. Ibid.; St. Louis Glot Democrat, April 29, 1902, p. 13, col. 4. Appeals were pending on this issue when t case became moot because of Lajoie's and Bernhard's transfers to Cleveland. Philadelph Public Ledger, May 3, 1902, p. 22, cols. 3-4; May 6, 1902, p. 14, col. 4; Míy 7, 1902, p. 1 col. 3; June 12, 1902, p. 16, col. 6. 
contracts. Since the inception of uniform player contracts in 1879, every player contract has contained a clause by which the player promises to perform exclusively for his contracting club during the period of the contract, usually one year. ${ }^{71}$ The general rule at common law is that personal service contracts are terminable at will with the breaching party liable only for damages. Injunctive relief to require specific performance will not lie, partly because of the long established policy against involuntary servitude. ${ }^{22}$ Equity will, however, enjoin the breach of negative covenants not to serve a competing employer when the performer's services are unique and when the contract is definite, not lacking in mutuality, and not void as a restraint of trade. ${ }^{78}$ Attempts by ball clubs to enjoin players from contract-jumping by such "negative specific enforcement" have been almost as unsuccessful as attempts to prevent reserve-jumping. Of ten attempts, petitioning clubs in organized baseball obtained injunctions in only four cases, and in all of these successful cases the players refused to return to their first-contracted employer. ${ }^{74}$

71. The first uniform player contract is reprinted in HEArINGS, 1514-6; those used in the major and minor leagues in 1951 appear in HeArings, 1248-59.

72. 5 Corbin, Contracts $\$ 1204$ (1951).

73. The leading case announcing this doctrine is Lumley v. Wagner, 1 De G.M. \& G. 603 (1852), in which Miss Wagner, the famous opera singer and niece of the great composer, was enjoined from performing for a competitor of her employer. Sce also Roy v. Bolduc, $140 \mathrm{Me}$. 103, 34 A.2d 479 (1943), and 5 Corbin, Contructs $\$ \$ 1205-12$ (1951).

74. American Association Base Ball Club of Kansas City v. Pickett, 8 Pa. County Ct. 232 (C.P. 1890) ; Cincinnati Exhibition Co. v. Marsans, 216 Fed. 269 (E.D. Mo.. 1914); Cincinnati Exhibition Co. v. Johnson, No. 612, C.P., Pittsburgh, Pa., Sept. 2, 1914; Indianapolis Athletic Ass'n, Inc. v. Burk, No. 740, C.P., Pittsburgh, Pa., Aug. $12,1915$.

The Pickett injunction was dismissed by consent of the plaintiff in return for the withdrawal of a counter-suit, Players' National League Base Ball Club of Philadelphia v. Mycrs et al., No. 1167, C.P., Philadelphia, Pa., Philadelphia Public Ledger, June 5, 1890, p. 8, col. 6. The Marsans injunction was dismissed after one year. Cincinnati Exhibition Co. v. Marsans, No. 4314, E.D. Mo., Aug. 19, 1915 (Opinion, Record on Appeal, 69-75), appeal dismissed, 232 Fed. 1020 (8th Cir. 1915). Johnson and Burk remained with their clubs, preferring to avoid the jurisdiction of the Pennsylvania courts rather than to return to organized baseball. Turkin \& Thompson, Offictal Baseball Encyclopedia 38, 158 (1951).

Unsuccessful bids by organized baseball included: American Base Ball \& Athletic Exhibition Co. of St. Louis v. Harper, 54 Cenr. L.J. 449 (St. Louis Cir. Ct. 1902) (lack of uniqueness, lack of mutuality, restraint of trade prohibited by Sherman Act and by federal and state constitutions); Brooklyn Baseball Club v. McGuire, 116 Fed. 783 (C.C.E.D. Pa. 1902) (lack of mutuality, lack of uniqueness); Baltimore Base Ball Co. v. Hayden and Wiltse, $14 \mathrm{~Pa}$. Dist. 529, $31 \mathrm{~Pa}$. County Ct. 500 (C.P. 1905) (improper for equity to grant such drastic relief without hearing all interested parties); Cincinnati Exhibition Co. v. Johnson, 190 Ill. App. 630 (1914) (lack of mutuality); American League Baseball Club of Chicago v. Chase, 86 Misc. 441, 149 N.Y. Supp. 6 (Sup. Ct. 1914) (lack of mutuality, restraint of trade).

Retaliatory suits by independent leagues seeking to restrain players from jumping 
Unable to obtain the assistance of the courts of equity either in enforcin the reserve rule or in preventing players from jumping existing contract: organized baseball has been forced to rely on extralegal methods to keep player in line. It has not sought court enforcement of the reserve clause since 190 and of the uniform player's contract since 1915. To prevent clubs in organize baseball from tampering with players under contract or reservation with othe members, it uses such threats as fines or forfeiture of games. To keep player from yielding to tempting offers from clubs outside the combination, it relie on the blacklist. And to discourage outsiders from making such offers, it use

back to organized baseball have been equally unsuccessful: Thorner v. Wise, No. 172 C.C.D. Mass., May 12, 1882 (no jurisdiction over parties); Thorner v. Wise, No. 306 Sup. Jud. Ct. Mass., May 17, $18 \$ 2$ (no temporary restraining order issued; case lat settled out of court); Allegheny Base Ball Club v. Bennett, 14 Fed. 257 (C.C.W.D. P: 1882) ; St. Louis Athletic Ass'n v. Mullane, No. 3642, C.C.S.D. Ohio, Mfay 13, 18 (opinion reprinted, Sporting Life, May 21, 18S4, p. 2, col. 1) (rejecting doctrine Lumley v. Wagner) ; Baltimore Base Ball \& Exhibition Co. v. Childs, 1 Balt. City Re: 169 (1891) (withdrawal of American Association from National Agreement construs as repudiation of contract); Columbus Base Ball Club v. Reilly, 25 Ohio Dec. 272 (1891 (lack of uniqueness, adequate remedy at law); Weegham v. Killefer, 215 Fed. 239 (61 Cir. 1914), affirnising 215 Fed. 168 (W.D. Mich.) (unclean hands in inducing player 1 ignore reserve clause of prior contract).

Legal battles within organized baseball for players' services have been rare due 1 the efficiency of the combination's self-regulation. The first such case to arise was $\mathrm{Da}_{\mathrm{a}}$ v. Smith, CO-18s6, N.Y. Sup. Ct, N.Y. County, Sept. 30, 18\&5. John ("Phenomenal" Smith, a young pitching sensation, signed an 1887 contract with the New Yorl: Giant then signed to play with Detroit for the remainder of the 1886 season. The court ordere Detroit to refrain from employing Smith until it agreed not to reserve him for the 188 season as it was entitled to do under the National Agreement. Sporting Life, Oct. 6, 18\& p. 1, col. 1. In Harrisburg Base Ball Club of York v. Athletic Ass'n of Harrisburg, Pa. County Ct. 337 (C.P. 1890), the court rejected the doctrine of Lumley v. Wogne and the Harrisburg club was able to retain the services of contract-jumper Franl: Gran one of the last Negro players to play in organized baseball prior to the imposition c the color ban. When the New York Giants in 1903 induced shortstop Gcorge Davis t desert the Chicago White Sox in violation of the truce agreement betwicen the America and National Leagues, Chicago successfully enjoined the breach of contract. Ameriea League Base Ball Club of Chicago v. Davis, No. 240340, Cools County (IIl.) Cir. Ct July 3, 1903; and No. R-S505, C.C.S.D.N.Y., July 15, 1903. The Giants sought to If taliate by enjoining Norman "Kid" Elberfeld from playing with the New Yorls High landers in the American League. Elberfeld had signed two 1903 contracts, one with th Giants and the other with Detroit; the Highlanders bought the Detroit contract for $\$ 5,004$ The injunction was denied on the ground that the Giants waived any claim to Elbarfeld services by signing the peace pact with the American League. National Evhibition C v. Elberfeld, CO-1903-N-409, N.Y. Sup. Ct., N.Y. County, July 15, 1903.

Players have not been the only contract-jumpers. Branch Rickey, who breached hi contract with the St. Louis Browns to become president and business manager of th St. Louis Cardinals at twice the salary, was enjoined in St. Louis American League Base ball Co. v. Rickey, No. 9320-B, St. Louis Cir. Ct., April 5, 1917; later dismissed b consent of plaintiff, N.Y. Times, April 7, 1917, p. 10, col. 5 . 
the boycott. Where blacklisting and boycotts prove ineffective, it supplements them with spirited salary wars. ${ }^{75}$

Today, organized baseball's agreements establishing a player monopsony are manifested in both the uniform player's contract and the trade regulations. Each player contract contains a reserve clause granting the club or its assignee the right to renew the contract for the succeeding year on all of the same terms except salary. If player and club are unable to agree as to new salary terms, the contract authorizes the club to fix the salary itself. In the major leagues the club may not reduce the salary by more than 25 percent; in the minor leagues the only limit to the club's discretion is the possibility of the player abandoning his calling. Because each new contract also contains an identical reserve clause, the club or its assignee has a perpetual option on the player's services. ${ }^{76}$

Teeth to enforce the reserve rule are provided in the Major-Minor League Agreement. The Major League Executive Council and the president of the National Association are there authorized to prescribe the form of the uniform player's contract. No club or player may sign a contract varying from specifications, including any waiver of the right to reserve, without the consent of the Executive Council, in the case of major leagues, or the National Association president, in the case of minor league contracts. Making any agreement not embodied in the uniform contract without such consent from the authorities subjects both player and club to disciplinary action. ${ }^{77}$

Supplementing this provision for a uniform contract is the requirement that each club annually file a list of players it is reserving for the ensuing season. These lists are then combined and circulated throughout organized baseball.

75. House Report, 35, 47-8, 50-3, 60, 77-82, 114-118. Organized baseball has also obtained an unexpected assist from the Immigration Commission in enforcing its player monopsony. The Commission, in construing the new McCarran-Walter Immigration Act, Pub. L. No. 414, 82d Cong., 2d Sess. (June 27, 1952), has assured the industry that foreign players who are admitted to play with organized baseball will be subject to immediate deportation if they jump their contracts. N.Y. Times, Jan. 23, 1953, p. 23, col. 2.

76. House REPORT, 112-113, 118. The present reserve clause in major league contracts reads as follows:

"On or before February 1 (or if a Sunday, then the next preceding business day) of the year next following the last playing season covered by this contract, the club may tender to the player a contract for the term of that year by mailing the same to the player at his address following his signature hereto, or if none be given, then at his last address of record with the club. If prior to the March 1 next succeeding said February 1 , the player and the club have not agreed upon the terms of such contract, then or before 10 days after said March 1, the club shall have the right by written notice to the player at said address to renew this contract for the period of 1 year on the same terms, except that the amount payable to the player shall be such as the club shall fix in said notice; provided, however, that said amount, if fixed by a major league club, shall be an amount payable at a rate not less than 75 percent of the rate stipulated for the preceding ycar." House Refort, 113 n.66; Hearings, 1251-2.

77. Major-Minor League Rule 3(a). Hearings, 1159. 
"[N]o player on any list shall be eligible to play for any other club until his contract has been assigned or until he has been released."78 If a player refuses to sign a contract with his reserving club, he becomes ineligible to play for any club in organized baseball. ${ }^{79}$ On being removed from the blacklist, he can play only with the club which last had option on his services. Commissioner of Baseball and the National Association president administer these blacklisting provisions. ${ }^{81}$

Of 8,000 active players in 1951, only eight held contracts without a reserve clause. Forty minor league players attempted to obtain contracts with this clause stricken, but the president of the National Association refused to approve thirty-two of them. No player in the major leagues has attempted to obtain a contract waiving the reserve clause since before $1921 .^{82}$

Aside from the rare player who obtains permission to sign a contract omitting the reserve clause, the only players on the free market are "free agents" -unwanted players who have been released or young rookies just entering the profession. To ease the pressure for higher salaries caused by these free agents and the zealous club owner, forty-two of the forty-five leagues have buttressed the reserve rule with agreements fixing salary limits. ${ }^{83}$ These agreements, contained in the league constitutions, prescribe an identical maximum monthly payroll for each member of the same league. They prevent any league member from being too liberal in its discretion in fixing the salaries of reserved players. However, their effectiveness in depressing salaries of free agents has been limited by the practice of paying bonuses to desirable new players. Such bonuses are not presently counted in the salary limits.

Organized baseball's monopsonistic agreements in the player market brought stability to the industry and, at least for the major leagues, prosperity. The reserve rule enabled club owners initially to reduce player salaries to levels where it was possible to balance the budget. It also brought the unanticipate! blessing of more equal competition on the playing field, increasing both attendance and profits. ${ }^{84}$ Player salaries, after an initial decline, also increased, although not in proportion to the rise in the clubs' revenue. Whereas major league gross receipts in 1950 were eighty times the $18 \$ 3$ level, ${ }^{85}$ the average

78. Major-Minor League Rule 4(a). Henrisgs, 1162.

79. Major-Minor League Rule 15. Heirnas, 1171.

80. Major-Minor League Rule 16(a). Hearisiss, 1171-2.

81. Major-Minor League Rule 15, 16. Hensnos, 1171-2.

82. HOUSE REPORT, 170.

83. Only the two major leagues and the Pacific Coast League are without salary limits. House REPORT, 121. Authorization for league salary limits is contained in the National Association Agreement, art. 18. Hensrass, 1209. For a synopsis of league salary limits, 1910-51, see Heskings, 1350-92.

84. HOUSE REPORT, 23-5.

85. Gross receipts for the sixteen major league clubs in 1883 was approsimately $\$ 480,000$. This rose to about $\$ 38,600,000$ by 1950 . Hovse REFont, 86 . 
major league player's salary was $\$ 11,000^{86}$ or only seven times that of $1883 .^{87}$ The consumers price index tripled between 1883 and 1950.88

The reserve rule has had far-reaching effects on the economic behavior of clubs in organized baseball. Expenditures which once were allocated to player salaries have now been diverted to other markets in the competition for player talent. The share of major league expenses devoted to paying actual producers of the game dropped from 67 percent at the time the reserve rule was adopted ${ }^{89}$ to 35 percent in 1929 and 22 percent in 1950.90 Major league clubs in 1950 allocated from 25 to 40 percent of their expenditures for the purchase of player contracts and the search for new players who had not yet signed contracts which removed them from the free market.01

In the minor leagues, salaries are considerably below major league levels. The average monthly salary for players in the AAA leagues in 1951 was $\$ 850$; in the AA leagues, $\$ 600$; in the A leagues, $\$ 350$; in the B leagues, about $\$ 250$; in the $C$ leagues, about $\$ 200$; and in the $D$ leagues, $\$ 165 . .^{02}$ Players in the A, B, C, and D leagues were receiving less in 1950 than players in the same classifications in 1929 despite the 37 percent increase in the cost of living. ${ }^{33}$

\section{The Farm System: Vertical Integration}

In the free market existing prior to the adoption of the reserve rule, the best player talent gravitated to the major league clubs whose larger consumer markets enabled them to offer higher salaries. Because each club sought the most skillful players it could afford, players advanced to higher-paying clubs as their ability warranted. The reserve rule did not arrest this flow of talent from the smaller clubs to the larger ones. Instead, it shifted buyer attention from the player himself to the club which "owned" the exclusive right to employ the player. The commodity representing this intangible right bestowed by "baseball law" was the uniform player contract.94 While players

86. HOUSE REPORT, 110. This figure represents the median salary. The mean salary was somewhat higher $(\$ 13,288)$ due to the presence of a few high-salaried stars. Itid.

87. The median salary of 30 players for whom 1883 salary data are available was \$1600. Spalding Base Ball Guide, 1890; Harky Wright, Note and Account Books (unpublished records in N.Y. Public Library).

88. The consumers price index (1935-39 base period, Bureau of Labor Statistics, Federal Reserve Bank of New York) rose from 57.3 in 1883 to 171.9 in 1950. Dep'r or Commerce, Historicat Statistics of the United States, 1789-1945, p. 235 (1949); Dep't of Comarerce, Statistical Abstract of the United States 278 (1952).

89. House REPORT, 21, 109.

90. Hearings, 1611; House Report, 109.

91. The Chicago Cubs allocated $\$ 813,054$ of $\$ 2,098,000$ total expenditures for "player replacement," Hearings, 871, 1609; and the New York Yankees, $\$ 946,268$ of $\$ 3,715,000$ (including $\$ 668,000$ income taxes), Hearings, 873, 1605.

92. House Report, 110; Hearings, 965, 1612.

93. Hearings, 1611.

94. See note 59 supra. 
lost any influence over their advancement to higher-paying clubs, promotion remained possible through the medium of this artificial market for contracts, in which clubs were both buyer and seller.

The past sixty years have been marked by a continual narrowing of the market for player contracts. Not only has organized baseball monopsonized the player market to the exclusion of independent leagues, but within the combination individual clubs have attempted to engross the cream of promising new talent. One manifestation of this combination within a combination is the farm system, organized baseball's version of vertical integration.

At first the major leagues were reluctant to allow minor league clubs to reserve players. To do so meant that the majors could obtain player replacements only by paying "exorbitant" prices to minor league clubs for the transfer of player contracts. The minor league clubs, however, found that without the assurance of a nucleus of a team from year to year and the power to regulate salaries they could not survive. The result was a compromise, reached in 1892. The majors granted the minors the right of reserving players but insisted in return that at the end of each season the majors be permitted to "draft" the contracts of promising players at fixed prices. The minor leagues were divided into two classes, $A$ and $B$, according to their financial strength. Major league clubs could draft any player contract from an $A$ league for $\$ 1,000$, and clubs in both the major and $A$ leagues were allowed to acquire contracts from $B$ leagues at $\$ 500$ apiece. 05

The compromise brought added stability to the minor leagues and enabled the major leagues to acquire the best talent available at a nominal cost. In addition, the annual draft stimulated activity in the market for player contracts. A minor league club, hoping to realize more on the inevitable advancement of a promising player to a higher classification, usually attempted to sell the player's contract at an advantageous price before the draft period began. The combined result guaranteed the players an opportunity to rise to the top of their profession without being chained indefinitely by the reserve rule to a poorly paying club. ${ }^{36}$

Ambitious major league clubs have frequently tried to engross the supply of minor league player contracts. At first some clubs drafted or purchased player contracts wholesale each fall, took their pick of players in the spring, and then "farmed" the remaining players to minor league clubs with agreements that they would be returned before the next draft period. Other clubs found that control of players was more successful when they purchased clubs in the minor leagues. ${ }^{97}$ From the turn of the century until 1914, the combination made determined efforts to block these maneuvers by prohibiting farming, limiting each club to the control of thirty-five players or less, and barring the ownership of minor league subsidiaries. ${ }^{38}$ Enforcement of these limita-

95. HOUSE Report, 36, 142.

96. Id. at $142,14+5$.

97. Id. at $44-5$.

98. Id. at 44-6, 156-9, 181 . 
tions began to wane in 1914, when the Federal League, advertising itself as a third major league, challenged organized baseball's player monopsony. Such enforcement collapsed entirely by 1920 , when the revelation of the Black Sox scandal prompted the major leagues to replace the National Commission with a single Commissioner, Judge Kenesaw M. Landis. In the interim the modern farm system gained a foothold it never relinquished. ${ }^{00}$

Pioneering the movement toward vertical integration were the St. Louis Cardinals, under the genius of their general manager, Branch Rickey. Beginning in 1920 with the purchase of an obscure club in Arkansas, the Cardinals amassed a minor league empire which at its height controlled twenty-eight clubs : thirteen owned outright and the remainder controlled by working agreements. This farm system developed three times as many major league players as the Cardinals needed to remain in pennant contention. Therefore, the Cardinals maintained a policy of selling the contracts of their older or unneeded players to other clubs, realizing income that made them the most profitable enterprise in the National League. ${ }^{100}$

To keep from being frozen out of the market for new players, other major league clubs were themselves forced to enter farming. The industry's rules were periodically circumvented or amended, over the opposition of Commissioner Landis and a minority of the club owners, to keep pace with these farming ventures. ${ }^{101}$ Both the number and percentage of independent clubs in the minor leagues have constantly dwindled. By the end of the 1952 season, major league clubs controlled 175 of 319 clubs in the minor leagues. ${ }^{102}$

Today only skeletons remain of the rules which originally were designed to keep the market in player contracts open and to ensure the advancement of players commensurate with their ability. The draft, which once assured every player in the minor leagues of an opportunity for advancement, now covers barely ten percent of minor league players. ${ }^{103}$ Fewer independent clubs remain which have player contracts to sell; fewer clubs are in the market to buy, since most major league clubs today rely on their own farm systems to supply replacements. Players who have signed with one of the major league farm organizations must rely on the judgment of one major league club for

99. Id. at $60,62-74,159$.

100. Id. at $63-5,94-5$.

101. Id. at 6474.

102. Sporting News, Dec. 3, 1952, p. 23, col. 4; National Associntion, 1952 HigirLIGHTS passin (1952). In 1927 all but 18 minor league clubs were independent. House REPORr, 65-6. In 1951 there were 169 independent clubs compared to 195 farm clubs. Id. at 188 .

103. House REPORT, 144-6. In the early part of the century, major league clubs drafted close to 100 players each year from the minor leagues. Id. at 145 . In 1952 they drafted only 11. Sporting News, Dec. 10, 1952, p. 9, col. 1. Of approximately 7,000 minor league players, 117 were drafted by minor league clubs of higher classification in 1952. Id. at col. 5 . 
their advancement. Frequently, a player of recognized major league ability languishes in the minors for years, simply because the parent club has his playing position adequately filled and will not sell his contract to a competitor.104 In short, for a majority of players in the minor leagues, advancement no longer is based on the judgment of all clubs in higher classification exercised through a universal draft and a free market, but on the judgment of one farm organization. ${ }^{105}$

The disappearance of the free market for player contracts which typified organized baseball 35 years ago has had far-reaching effects on the distribution of baseball expenditures. It has diverted clubs' attention to the one free market remaining: the market for free agents. The New York Yanliees spend one million dollars annually-one-third of their operating budget-on player development. The bulk of this is spent on scouts, tryout camps, and bonuses, all used to lure teen-age prospects into the Yankee farm system. ${ }^{100}$ Other major league clubs, not blessed with consumer markets of comparable size, spend somewhat lesser amounts. The situation has not been rare when a boy has been besieged by sixteen offers on the day after his high school graduation, when the hunting season officially begins. ${ }^{107}$ Bonuses to these roolies, most of whom will never make the big leagues, range up to $\$ 150,000^{103}$ and in

104. See, e.g., Horse Refort, 15S: Hoffman, Toby Finally Gols a Frcal, Baseball Digest, Oct. 1952, pp. 81-4.

105. Indicative of the degree to which the reserve rule and the farm system have retarded the advancement of players to the highest rung of their profcssion is the average age of new major league players. In the $1 \$ 70 \mathrm{~s}$, the era of a completsly frce marliet, the average age of the major league roolie was 22 . In the 1880 's, when the reserve rule applied only to the major leagues, the averagu age was 23. From 1892 to 1919, when the reserve rule extended throughout orsanized baschall but virtually all minor league players were subject to the draft, the average age was 24 . From 1920 to 1939 , with a restricted draft and fewer than half of the major league clubs possessing farm systems, the average age rose to 25 . During the $1940^{\circ}$ s, when the farm system beame the rule rather than the exception, the average age of a major league roolsie was 27 . This information is compiled from a random sample of players who particirated in major league games, 1871 to 1949, as reported in Tunkm \& Thosrpson, OFrictal B.tsenul ExcrclopenI 3-3 49 (1951). Participation in an accumulated number of games equal to the following proportions of the major league schedule was used as the criterion fur determining the age at which a player became a "major leaguer": pitchers, 1/10th; catchers, $1 / 4$ th; and other players, $1 / 3 \mathrm{~d}$.

The probative value of such evidence is, of course, tempered by the unlnown effect of other variables such as military conscription and changes in the caliber of major leagre play.

106. Hearings, 873, 1605.

107. Daley, Price-Fizing Nceded, N.Y. Times, June 4, 1951, p. 33, col. 5.

108. The Cleveland Indians were reported to have paid rookie pitcher "Billy Joe" Davidson a $\$ 150,000$ bonus on the day atter his high school graduation for signing with their farm system. N.Y. Times, May 30, 1951, p. 16, col. 5. For reports on the 1952 bonus orgy, see Sporting Xiews, June 25, 1952, 1. 4, cul. 1; July 2, 1952, 1. 1, col. 5. 
1951 totaled $\$ 4,500,000,{ }^{109}$ which was almost equal to the aggregate salaries of all active major league players. ${ }^{110}$

Opinions differ on the effect of the farm system upon minor league clubs. Some assert that absentee control ruins fan interest in the home town club. Others maintain that the minor leagues could not exist today without major league financial and operational assistance. They claim that the glamour of affiliation with a major league club actually enhances paid attendance. Despite the fact that minor league farms are operated chiefly to develop players for the parent club and only secondarily for the fans of the area, many minor league clubs openly solicit major league tie-ups, knowing that they bring financial and player assistance to the club. Independent minor league clubs, unable to match the resources of farm organizations, generally must be satisfied with overlooked youngsters or overage veterans on their way down from higher leagues. ${ }^{111}$ As a consequence, minor league clubs blessed with farm system ties not only control the best players, but also dominate the pennant races of their respective leagues.112

\section{Division of Consumer Markets}

The oldest restraint in professional baseball is "territorial rights," a euphemism for the division of consumer markets. When the National League organized in 1876 , one of its chief attractions to member clubs was the provision in its constitution that no more than one club would be admitted from any city. Experience in the old National Association (1871-75) had indicated that two or three competing clubs in the same city usually spread attendance too thin for the success of any club. By limiting each city to one club, the National League hoped its members would have greater chance for financial success.113 The rule also deprived the customers of any choice in selection and permitted clubs to fix admission prices. ${ }^{114}$

109. Sporting News, Nov. 12,1952 , p. 8 , col. 1. Sweeping restrictions on the payment of large bonuses were imposed by amendments to the Major-Minor League Rules in December, 1952. Players who sign their initial professional baseball contracts for a salary and bonus above $\$ 5,000$ in the major leagues, $\$ 4,000$ in the minor leagues of " $\mathrm{A}$ " classification or higher, and $\$ 3,000$ in the lower minor leagues are designated "bonus players." Minor league bonus players are then subject to unrestricted draft before they may be transferred in any manner to another club. Bonus players signed directly to major league contracts must be retained for two years unless given an unconditional release. Id. at col. $3 ;$ id., Dec. 17,1952, p. 7 , col. 5 .

110. The 399 players employed by major league clubs as of July 1, 1951, were receiving annual salaries totaling $\$ 5,291,850$. HearIngs, 965 .

111. House Report 108, 185-7 and notes.

112. Of 36 minor leagues in which major league clubs had farms in 1952, only eight independent clubs won pennants. Sporting News, Dec. 3, 1952, p. 23, col. 2.

113. House Report, 19; Hearings, 1513.

114. Initially the National League fixed admission prices at fifty cents. House REPORT, 20. 
"Territorial rights" became an integral part of the first National Agreement ${ }^{115}$ and has remained a fundamental part of the code of organized baseball down to the present day.110 Whether a new professional league could gain admission to organized baseball depended in large degree on whether it intended to place clubs in cities "belonging" to clubs already in the combination. The rare occasions where leagues have been admitted which encroached on existing franchises have been the result of inconclusive baseball wars. ${ }^{117}$

The justification for these local monopoly grants is that one healthy club in a particular city is better than two or more starving ones.118 On the assumption that consumer demand for professional baseball is limited in each metropolitan area, clubs in organized baseball have insisted on a veto power over the invasion of their markets by interlopers. Because each club relies on road receipts for part of its income, it also has insisted on authority to block: moves of league rivals to less lucrative or doubtful marketing areas. ${ }^{110}$ Traditionally, clubs in organized baseball have been unwilling to permit each club's individual discretion to determine whether a city presently occupied can support another club or whether a city without baseball can support a new club.

This division of consumer markets has been further complicated by the passage of time. Local market monopolies, once bestowed, have become capitalized as part of the assets of each club and have strengthened the resistance of clubs against any relaxation of the rules, which would jeopardize these "investments." 120 The traditions and identification with the community established by many of the older clubs have raised further barriers to any relaxation of territorial rights. Furthermore, the multiplication of leagues within organized baseball has complicated the problems of moving established franchises. Any move of a major league club to a city not presently represented in the majors may necessitate a complicated chain reaction of readjustments: throughout the minor leagues.

By entrenching major league clubs in most of the choice consumer marliets, the rules on territorial rights strengthen the dominion of the major leagues. Having established themselves in the most lucrative cities, major league clubs

115. $18 \$ 3$ National Agreement, as amended 18\$9, Horse Repokt, 27.

116. Míajor League Rule 1. Hearings, 1125.

117. House RePORT, 26, 38-42.

118. This was the major selling point of territorial rights when the rule was first adopted in 1876. Hearings, 1510, 1513.

119. In $18 S 5$ the president of the Metropolitan Base Ball Association transferred his American Association club from Manhattan to Staten Island, hoping thereby to increase the revenue of his ferry boat line. After his enraged league rivals summarily espalled the Mets from the American Association, the club successfully enjoined the ouster for want of just cause. Metropolitan Base Ball Ass'n v. Simmons, 1 Pa. County Ct. 134 (1885) ; House Report, 30. Since that occasion, inter-club and inter-league agreements have effectively thwarted such club discretion.

120. Commissioner Frick testified before the Antitrust Subzommittee that the barriers to franchise shifts had been increased by revisions in the rules on territorial rights "because of values more than anything else." Hensisas, 110. 
possess the economic power to dictate modifications in the trade rules regarding the control of players or of consumer markets. ${ }^{121}$ Minor leagues may not unilaterally violate the restrictions on player employment or market locations without risk of explusion from organized baseball. ${ }^{222}$ If expelled, they lose their territorial rights and player monopsony privileges and, in any trade war with the wealthier major leagues, may even risk annihilation.

Today only five cities are represented by more than one club. New York has three major league clubs ;23 Chicago, Philadelphia, and St. Louis each have two. ${ }^{124}$ Los Angeles has two representatives in the Pacific Coast League. ${ }^{125}$ Franchise shifts to territories already represented in organized baseball have been virtually impossible under the combination's agreements. Transfer of a major league club requires the approval of at least a majority of its league competitors. If the transfer is to a city already occupied by the other major league, unanimous approval of all major league clubs is required.120

121. Gross operating income for major league clubs in 1950 ranged from $\$ 737,000$ (St. Louis Browns) to $\$ 4,212,000$ (New York Yankees) with $\$ 2,000,000$ the average. Hearings, 1605,1609 . The largest operating income in the minors was $\$ 599,000$ (Oak: land, Pacific Coast League) with $\$ 300,000$ the average in the five largest minor leagues. Id. at 1629-35. To obtain the benefits of player reservation and territorial rights for themselves, minor leagues were forced to enter the combination begun by the major leagues on the major's own terms. Today, amendment of the Major-Minor Leaguc Agreement and Rules requires the approval of both major leagues (or one major leagute and the Commissioner) and three-fourths of the leagues in the National Association. Id. at $1124,1175-6$. Since major league clubs own or control about 60 percent of minor leagute clubs, they can effectively thwart any changes proposed by independent clubs and are virtually assured of being able to pass their own amendments. This situation brought angry threats from the independent Dallas (Texas League) club at the last minor leagtte convention: "If this Association refuses to remove the existing inequities and centralization of power of control in the hands of a few members of this Association who are controlled by a few major league clubs, the independent minor league club owners will be forced to seek equitable relief elsewhere." Sporting News, Dec. 10, 1952, p. 5, cols. 2-3.

122. National Association Agreement, $\S \S 10.02(\mathrm{a}), 10.05,30.03$. Henkrngs, 1194-5, 1237.

123. New York Yankees, Inc.; National Exhibition Co. (Giants); and Brooklyn National League Baseball Club, Inc. (Dodgers).

124. American League Baseball Club of Chicago, Inc. (White Sox) and Chicago National League Ball Club (Cubs); American Baseball Club of Philadelphia (Athletics) and Philadelphia National League Club (Phillies); American League Baseball Co. of St. Louis (Browns) and St. Louis National Baseball Club, Inc. (Cardinals).

125. Los Angeles Baseball Club (Angels) and Hollywood Baseball Association (Stars). San Francisco-Oakland and Minneapolis-St. Paul, which are classified by the United States Bureau of Census as single metropolitan areas and which are, perhaps, con* tiguous market areas, are also represented by two clubs.

126. These rules represent a slight relaxation of the former major leagute provisions for club transfers. Prior to December, 1952, Major League Rule 1(c) required unanimous consent from the interested club's league and majority approval of the other major league. Hearings, 1125. Following the severe censuring of the rules on territorial rights by the Antitrust Subcommittee (see House REPORT, 189-203), the major leagues modified Rule 1 (c) to its present form. Under the new rule, transfer of a National League franchise 
On the other hand, if a major league club desires to invade minor league territory, it must secure the consent of both the minor league and the club concerned or pay "just and reasonable compensation" as determined by negotiation or arbitration. ${ }^{127}$ No minor league club can encroach upon major league territory without written consent of the league concerned-3 highly unlikely possibility. ${ }^{123}$

The alleged purpose of "territorial rights" is "to preserve and stimulate competition for the League Pennant." 129 The result, however, has been industrial rigor mortis, with clubs placed at the mercy of population shifts and competitors' vetoes. Prior to 1953, the last shift in the major leagues occurred in 1903, when the Baltimore American League club moved to New Yorl: City in defiance of the National League, then at war with the "outlaw" .Imerican circuit. ${ }^{130}$ The long overdue realignment to adjust to population shifts did not commence until March 18, 1953, when the Boston Braves persuaded National League rivals to consent to the transfer of the Boston club to Milwaukee. ${ }^{12 R_{3}}$ All other reported attempts to move franchises during the fifty intervening years have been frustrated by interested competitors. ${ }^{131}$ Shifts of minor league

to a non-major league city requires approval of five National League clubs; in the American League, six. Unanimous consent of clubs in both leagues is till ruquired if the transfer is to any city in the other major leasue. Sporting News, Dec. 17, 1052, p. 7 , cols. 2-4.

127. Major-Minor League Rule 1(a). HenRrints, 1157-S.

128. Major-Minor League Rule 1(b). Henkngs, 1158. The last ocariun un vilin at league invaded "major league territory" was in 1913 and 1914, when this Fidcral League was organized. This move, coupled with the inasion of organizul lasclall's player monopsony, touched off the costlicst trade war in the game's histury: Hut + E Krerest. $50-6$.

129. Former Major League Rule 1(c). Heisungs, 1125.

130. House Report, 41, 190.

130a. N.Y. Times, March 19, 1953, p. 1, col. 2. The Braves securcd unanim us conlunt from other National League clubs and paid a reported $\$ 50,000$ to olitain the aryrubal 0.5 the American Association. The cost of the transier was minimized by the fact that th. Braves already owned the Milwauke franchise in the American Assuciation. Id. at $\mathrm{jl} .3$, col. 2 .

131. In 1915 the Baltimore Federal League club proposcd to luy the St. Louis Cardinals and shift the franchise to Baltinore as part of the "peace treaty" which was to end the Federal League war. Other National League clubs vetoed the plan, prominting the Baltimore Federals to take their grievance all the vay to the Supreme Court. House Report, 57. In the mid-Thirties, Frank Navin, president of the Ditruit Tigers, vetoed the Cardinals' plan to transfer their National League franchise to the Motor City. HoUse REPORT, 76. In 1941 the St. Louis Browns were in the process of completing plans for a hop to Los Angeles when the war intervencd. Before the war terminatcd, the Pacific Coast League succeeded in amending the Major-Minor League Agreement to its present form so as to make any revival of the plan a financial impossibility. Ilid. Rccently the Browns made two more futile attempts to move. They offercd SE00,469 trituste to tire Boston Braves for the opportunity of transferring the club to Milwaulses, territory formerly "belonging" to the Eraves" farm club in that city; tut the Draves flatiy rijuct: 1 the offer. N.Y. Times, March 4, 1953, p. 32, col. 5. Subsequently, the Erowns made 
franchise invariably have been to areas without representation in organized basebal1. ${ }^{132}$ Fifty years ago the St. Louis area could easily support two major league entries. It was the second largest city in the country which permitted games on Sunday, the day when patronage is the greatest. Today all the major league clubs can play Sunday ball and St. Louis has the smallest population per club in either league. ${ }^{133}$ Its clubs, consequently, have been the poorest attendance-drawers over the past twenty-five years. ${ }^{134}$ The Cardinals have been able to stay in pennant contention by living off their farm system, ${ }^{185}$ but the Browns frequently have been forced to sell the contracts of capable players in order to stay solvent. ${ }^{136}$

Relatively small population areas mean inferior attendance, inferior receipts, and-unless outside money sources are available-inferior clubs. As clubs become shabbier on the playing field, attendance falls off even more and the vicious circle continues until the league finds an "angel" to pump new capital into the franchise. Such has been the history over the past three decades in St. Louis, Boston, Philadelphia, and Cincinnati, the "slums" of the major leagues. ${ }^{137}$

arrangements to shift their franchise to Baltimore, but this time five American Leaguc rivals vetoed the plan. N.Y. Times, March 17, 1953, p. 32, col. 1. Thus, Bill Veeck, president of the Browns, appears doomed to exhibit his club again to empty stands in St. Louis, where by his own admission the Browns lost $\$ 400,000$ in 1952. Daley, After the Knocliout, N.Y. Times, March 18, 1953, p. 42, col. 2. One can only guess as to the number of other desired transfers which never got beyond the speculation stage due to the rules on territorial rights.

132. In June, 1952, the Toledo club transferred to Charleston, W. Va, which had been without professional baseball since the demise of the Central League in 1951. Sporting News, June 18, 1952, p. 9, col. 5; June 25, p. 26, col. 4; July 2, p. 16, col. 3-5. This was the first franchise shift in the American Association since 1914-15, when ${ }_{a}$ the Toledo club was temporarily moved to Cleveland to discourage the occupancy of that city by" the Federal League. Heilbroner Baseball Bureau, lengues and Lengue Cities of Professional Baseball 9 (1941). During 1952 there were four other franchise shifts in the lower minor leagues to cities not represented in organized baseball. NATIONAL Assoctation, 1952 Highlights passim (1952).

133. Hearings, 1696-7: House Report, 98-9, 191.

134. House Report, 101 ; Henrings, 1595-8.

135. House REPORT, 95, 102-03.

136. "From 1947 to June 15,1951 , the Browns netted $\$ 1,296,000$ in player transactions with other major-league clubs, enabling its management to transform a $\$ 500,000$ deficit into a $\$ 600,000$ profit"-after income taxes. House REPORT, 95. Bill Veeck, new president of the Browns, unable to move the club and unwilling to sell its players, has sought to equalize competitive conditions within the American League by increasing the visiting club's share of receipts for games it helps produce in other cities. His chief proposal -for home teams to share television receipts with the visiting club-was voted down. And in retaliation the New York Yankees, Boston Red Sox, and Cleveland Indians refused to book any night games in their parks with the Browns, thereby reducing attendance and the Browns' road income even further. N.Y. Times, Jan. 31, 1953, 1. 19, col. 3; Feb. 1, 1953, \& 5, p. 1, col. 4.

137. House Report, 95, 99-103; Hearings, 1591-1609. 
Monopolizing patrons, profits, and pennants have been the clubs with the fortuity of possessing franchises in large metropolitan areas. ${ }^{138}$ The three New York clubs, for example, have ranked no lower than third in attendance strength in their leagues since 1920 and have shared thirty-two pennants. ${ }^{139}$ Profits of the New York Yankees from 1920 to 1950 approached nine million dollars-more than six other American League rivals combined.140 Other clubs with profitable markets protected from invasion by the rules on territorial rights are the Detroit Tigers, Pittsburgh Pirates, Cleveland Indians, and Chicago Cubs. ${ }^{141}$ Detroit and Pittsburgh each have larger metropolitan areas than St. Louis, which has two clubs. ${ }^{112}$

Meanwhile, Los Angeles and San Francisco, two of the largest metropolitan areas in North America, are without representation in the major leagues, and, under existing rules, will remain "minor league" indefinitely. Baltimore, Buffalo, Montreal, Toronto, and Minneapolis-St. Paul also have marliets larger than some present members of the "big time." Kansas City and Houston are approaching this level.143

Territorial rights have their adverse effects on fans, clubs, and players alilie. Fans in minor league cities which could support major league clubs with relative ease are deprived of any opportunity to see championship games played by the industry's top performers. Fans in other cities, now represented in the majors, are doomed to witnessing perennial also-rans. Meanwhile, clubs located in territory labeled "minor league" fifty years ago cannot advance to major leagre circles without the consent of every interested competitor. Major league clubs with poor franchises are unable to move to greener pastures except at prohibitive cost and consent of from four to fifteen rivals. On the other hand, players of comparable ability receive widely discrepant salaries solely because of the wide gulf between good franchises and bad. Members of the last place Browns received half the salaries of players on the last place Cubs in 1950, while members of the pennant vinning Phillies earned one-third less than their counterparts on the New York Yankees, who finished first in the American League. ${ }^{144}$

138. See note 137 supra.

139. House REPORT, 101, 102. Much to the chagrin of fans outside of the Metropolitan New York area, both the 1951 and 1952 World Series were "subway series." In 1951 the Yankees played the Giants for the world championship; last year they played the Dodgers.

"Attendance strength," as the term was used by the Antitrust Subcommittes, is the measure of each club's share of its league attendance after eliminating the variations due to superior or inferior playing performance. Id. at 100-101.

140. HEARINGS, 1601.

141. Id. at 1592, 1596-7, 1601. Profits of the Chicago White Sox have been half those of the Chicago Cubs, perhaps due to the less desirable location of Comisliey parls Id. at 1601.

142. Id. at 93 .

143. Id. at 93.

144. Id. at 1610 . 


\section{Exclusion of Competitors}

The turbulent history of organized baseball has been marked by at least thirteen commercial wars with disfavored or "outlaw" leagues. ${ }^{145}$ The rensons for these wars were two: either the independent league refused to recognize existing "territorial rights" or else it refused to recognize organized baseball's monopsony on players' services. Frequently the independent committed both sins. ${ }^{146}$ The outcome of these wars was either extinction of the independent league ${ }^{147}$ or its merger with organized baseball., ${ }^{148}$ Only one league which has questioned the industry monopsony has survived and retained a semblance of independence. This lone survivor is the Mexican League. ${ }^{140}$

The tactics employed by organized baseball in these wars were boycotts, player blacklists, price wars for players' services, legal harassment, and the scheduling of conflicting games whenever the "outlaw" league had a club in territory claimed by the self-appointed captains of the industry. ${ }^{150} \mathrm{By}$ far"

145. The first, between the National League and the old American Association in 1882, resulted in a truce which created the inter-league combination now called organized baseball. These two leagues, supported by their minor league following, successfully demolished the Union Association in 1884 and the Players League in 1890. A dispute in dividing the player spoils after the demise of the Players League led to renewed war between the National League and American Association in 1891. This war terminatcd with the National League absorbing four clubs from its former ally and buying out the remainder. Ten years' tranquillity ended in 1901 when the American League promoted itself to major league status and fought the National League to a draw by 1903 . Meanwhile, a revived American Association invaded forbidden minor league territory and won reluctant acceptance into the National Association. The reorganized combination of major and minor leagues subsequently forced into surrender the Tri-State (1907) and California State (1909) leagues and eliminated a third outlaw, the Atlantic Association, in 1909. After a two-year war, the major leagues bought out the Federal League in 1915. Organized baseball's market monopoly has not been challenged since that time. Its monopsony in the player market, however, has been disputed by three foreign leagrtes in recent years: the Mexican League (1946), the Cuban Winter League (1946-47), and the Quebec Provincial League (1947-48). House Rerort, 26-9, 33-5, 38-42, 47-8, 50-7, 77-84; Lanigan, Baseball CYclopedia 112-113 (1922).

146. Disputes over players were involved in all thirteen trade wars; rivalry over consumer markets was an additional factor in the American Association war of 1882-83, the Union Association war of 1884, the Players League war of 1890, the American Association war of 1891, the American League war of 1901-03, the American Association war of 1902, and the Federal League war of 1914-15. House Repokr, 26-9, 33-5, 38-42, 47-8, 50-7, 77-84; Turkin \& Thondpson, Official Baseball Encyclopedia 405 (1951).

147. Union Association (1884), Players Ieague (1890), old American Association (1891), Atlantic Association (1909), and Federal League (1915). House Reront, 29, $35,56-7$.

148. Old American Association (1883), new American Association (1902), American League (1903), Tri-State League (1907), California State League (1909), Cuban Winter League (1947), and Quebec Provincial League (1949). House Reront, 26, 42, 47.8, 81,82 .

149. House Report, 82

150. Id. at $35,47,79$ (boycotts) ; $28,47,48,51,53,77-81$ (blacklists) ; 35, 40, 51-2, 55 (price wars) ; 34-5, 41, 54-5, 79 (legal harassment); 35 (conflicting schedule). 
the most effective weapon was the blacklist. Possessing a virtual monopsony on the player supply, organized baseball threatened the blacklisting from three years to life of any player who "jumped" his contract or ignored the reserve rule. As a result, competing independents were forced to offer bankrupting salaries in order to lure players to their clubs. ${ }^{161}$ If players wavered before these tempting offers, clubs in organized baseball were not adverse to offering substantial salary increases to keep them in line. ${ }^{162}$ On a few occasions the clubs induced players to break their contracts with independent leagues to return to the ranks of organized baseball.103

The last attempt to thwart the monopoly of organized baseball in the United States was the Federal League war of $1914-15$, a venture which cost its backers $\$ 2,500,000 .^{151}$ Since that time, organized baseball has completely dominated the American market-both in giving professional baseball exhibitions and in hiring professional baseball players. Various professional Negro leagues have existed independently during this period, but due to the

151. Id. at $35,40,51-52,55$.

152. Ty Cobb's salary jumped from $\$ 12,000$ to $\$ 20,000$ during the Federal League war. Walter Johnson's salary increased from $\$ 7,000$ to $\$ 20,000$. Id. at 52-3. Major increases in salary scales have always occurred during baseball price vars. Sometimes, however, salaries tumbled when organized baseball succecded in restoring its monopsony. The following are salaries of players on the Philadelphia Phillies in 1859, when the club's reservations claims were unchallengcd; in 1892, after the cessation of two years of free competition with independent leagues; and in 1893 , when the club ance more was able to exercise its discretion:

$\begin{array}{lrrr} & 1559 & 1592 & 1593 \\ \text { Clements } & \$ 2450 & \$ 3000 & \$ 1800 \\ \text { Delahanty } & 1750 & 2100 & 1800 \\ \text { Hallman } & 1400 & 3500 & 1800 \\ \text { Thompson } & 2500 & 3000 & 1800 \\ \text { Allen } & - & 3000 & 1800 \\ \text { Hamilton } & - & 3400 & 1800 \\ \text { Cross } & - & 3250 & 1800 \\ \text { Keefe } & - & 3500 & 1800 \\ \text { Weyhing } & - & 32: 0 & 1800\end{array}$

(Source: H. Wright, Note AND Accoust Books, unpublished records in N.Y. Public Library.)

153. Wade Killefer, catcher for Grover Cleveland Alewander, received $\$ 3,200$ playing for the Philadelphia Phillies in 1913. On January \&, 1914, he signed a three-year contract with the Chicago Federals at $\$ 5,833.33$ per season. Twelve days later he returned to his reserving club, signing another three-year contract at $\$ 6,500$ a season. House Rurerr, 55 . Chicago failed to enjoin the breach of his Federal League contract. Weeghman w. Nillefer, 215 Fed. 289 (6th Cir. 1914), affirming 215 Fed. 168 (D. Mich. 1914). Sce alco House REPORT, 52-3. Such salary wars are not inconsistant with organized baseball's blachlisting procedures, since a player does not become ineligible (i.e., blaclilisted) until he has actually violated his contract or reservation by playing on a forbidden club. Major League Rule 15(a), Hearngas, 1142; Major-MFinor League Rule 15(a), Heariacs, 1171; National Association Agreement, $\$ 21-01$, Henrisgs, 1212; House Kerumt, 23, 4\$, 77-8.

154. House Report, 56. 
color ban in organized baseball there was no market conflict. ${ }^{165}$ Since 1945, when the doors of organized baseball were opened to all races, ${ }^{100}$ the one surviving Negro league, the Negro American League, has recognized both contracts and reserve lists in return for similar guarantees from the ruling bodies of organized baseball. 157

Recent wars in the industry have occurred between organized baseball and leagues in other countries. In 1946 the Mexican League offered tempting bonuses and salaries to players in the major and high minor leagues who would agree to play south of the border. Senator A. B. Chandler, organized baseball's second commissioner, announced that any major lenguer who jumped his contract or reserve clause would be barred from returning for five years. As a result, only eighteen players ventured to accept offers from the Mexican League. The Cuban Winter League also became "outlaw" when it accepted these ineligible players for winter-time employment. Some players, disliking living conditions in the tropics, sought asylum with the Canadian Provincial League, and it too was labeled "outlaw." Other players attempted to play for semi-pro clubs in the United States, only to find the blacklist posted at every ball park controlled by organized baseball where they hoped to play their exhibitions. ${ }^{158}$

In 1947 organized baseball agreed to accept the Cuban Winter League as an unclassified affiliate and to permit it to borrow a limited number of minor league players each winter if it would bar its member clubs from contracting with the Mexican League ineligibles. Similar pacts were made with winter leagues in Panama, Puerto Rico, and Venezuela. ${ }^{150}$ A year later, Chandler and the president of the Mexican League agreed not to tamper with each other's players under contract or reservation, and the Canadian Provincial League, the last of the "outlaws," entered organized baseball as a Class " $\mathrm{C}$ " minor league. ${ }^{160}$ As a result, virtually all professional baseball leagues in America, from the equator to Hudson Bay, have subscribed by written or oral agreement to the monopsonistic agreement of organized baseball not to compete for players' services. ${ }^{161}$

155. Negroes played in organized baseball in the $1880^{\circ}$ s. From 1887 to 1891 , however, the leagues introduced segregation into professional baseball and for over half a century this color line was perpetuated by unwritten rules. CRAIG, OrGanized BASEanli 223.6 (unpublished thesis in Oberlin College Library, 1950).

156. Branch Rickey, then general manager of the Brooklyn Dodgers, signed Jackic Robinson, second baseman of the Kansas City Monarchs, to a Montreal contract in October, 1945. N.Y. Times, Oct. 24, 1945, p. 17, col. 1. Robinson thus became the first Negro to play in organized baseball in 55 years, and he was soon followed by many more.

157. Hearings, 1295-6, 1548-50.

158. HOUSE REPORT, 77-82.

159. Id. at 81 .

160. Id. at 82 .

161. In addition to the four "unclassified affiliates," there are two other winter leagues in Central America: the Mexican Pacific Coast League and the Veracruz Winter League. Sporting News, Dec. 17, 1952, p. 22, cols. 2-4. It is not known whether these 
Organized baseball today is complete master of the national game. One witness before the Antitrust Subcommittee characterized the combination as a "government within a government."162 This appears to be an understatement. The intricate provisions of baseball law, formulated by sixteen major league club owners and their minor league dependents and administered by Comissioner Ford C. Frick, minor league president George MI. Trautman, and forty-five league presidents, rule the sport wherever it is played professionally in North and Central America.

\section{Organized Baseball and the Sherman Act}

The assault on organized baseball's monopsonistic position is primarily in the hands of private parties. The Justice Department and the Federal Trade Commission have shown no inclination to act on behalf of the government. The investigation by the House Antitrust Subcommittee focused publicity on the combination, but congressional action was limited to pointed criticisms of the status quo in the industry. Therefore, the fate of organized baseball's restrictive practices will probably rest on the outcome of treble damage suits. Two of the present actions are by blacklisted players ${ }^{163}$ and one by a former minor league club owner, who allege damages arising from the reserve rule; $;^{10 t}$

two organizations adhere to the industry's reserve rule Even if they do not, however, they pose no threat to organized baseball's player monopsony.

162. Testimony of Frederic A. Johnson, Hensuags, \$77-\$, \$85-6.

163. Prendergast v. Syracuse Baseball Club, Inc ct al., No. 3936, N.L.X.Y., filc1 April 30,1951 , is a suit by a pitcher who was blacklisted for refusing to accept the assignment of his contract from Syracuse to Beaumont and a salary reduction from \$1,100 $\mathrm{per}$ month to $\$ 750$ per month. Claiming $\$ 300,000$ damages, Prendergast alleges that deiendants used the reserve clause and rules of organized baseball to deprive him of the reasonable value of his services from 1936-51 and that, by blacklisting him, they degrived him of his professional means of livelihood. Consideration of defendants' motions to dismiss have been delayed pending the outcome of the Toolson and Focislshi anpeals.

Toolson v. New York Yankees, Inc. et al., 101 F. Supp. 93 (S.D. Ca1. 1951), affd por curiam, 200 F.2d 198 (9th Cir. 1952), is a suit by another pitcher who was blaclslisted for refusing to accept the assignment of his services from Newark to Binghamton. Claiming $\$ 375,000$ damages, Toolson alleges that defendants have combined to monopolize professional baseball in the United States and, by blacklistung him, have deprived him of his means of livelihood. Plaintiff filed a petition with the Supreme Court for a writ of cartionri, March 7,1953 , seeking review of the order dismissing the complaint, 21 U.S.L. WEEK 323:.

164. Corbett and El Paso Baseball Club, Inc. v. Chandler ct al., No. 2589, S.D. Ohio, dismissed Jan. 25, 1952, aff'd, th Cir., Fed. 20, 1953. Cortett, former owner of this $\mathrm{El}$ Paso Baseball Club in the Class " $\mathrm{C}$ " Arizona-Tesas League, contracted for the 1949 services of four players who had $19+8$ contracts with the Mexiean League. Commissioner Chandler at that time had a reciprocal agreement with the Mesian League to respect reservation claims. President Trautman of the National Association enforced this agreement and awarded the four players to the Mesican League. Claiming $\$ 300,000$ damages, Corbett alleges that organized baseball is a monopoly based on the reserve rule which has deprived the El Paso Club of the four players' services and the opportunity to sell their contracts. Following the Sixth Circuit's decision affirming the dismissal, Corbett's attorney announced his intention to petition for a writ of certiorari. N.Y. Times, Feb. 21,1953 , p. 17, col. 1 . 
another player's suit challenges the farm system as well.105 Should any of these plaintiffs succeed, the number of treble damage suits may be expected to soar; if they lose, organized baseball will relapse into an uneasy truce with the antitrust laws.

\section{Jurisdictional Issues}

Three of the pending suits were dismissed by the district courts on the ground that they lacked jurisdiction because of the 1922 Fedcral Bascball case. ${ }^{166}$ In that opinion, Justice Holmes, speaking for a unanimous Supreme Court, held that the business of presenting professional baseball exhibitions for profit was neither interstate nor trade or commerce. Exhibitions, being "purely state affairs," did not become interstate because of the "incidental" interstate movement of clubs to play these games. Neither was the exhibition "trade or commerce . . . within the commonly accepted use of those words." According to Holmes, "personal effort, not related to production, is not a subject of commerce."107 The breadth of this opinion has given organized baseball an exemption which it would have been difficult for Congress to match.

165. Kowalski v. Chandler et al., No. 2646, S.D. Ohio, dismissed Jan. 25, 1952, aff'd, 6th Cir., Feb. 20, 1953. Kowalski, a minor league player since 1946, claims $\$ 150,000$ damages. He alleges that defendants used the draft restrictions and the uniform contract containing the reserve clause to deprive him of the reasonable value of his services and opportunities for promotion. Plaintiff's attorney intends to petition the Supreme Court for a writ of certiorari. N.Y. Times, Feb. 21, 1953, p. 17, col. 1.

A fifth suit alleging $\$ 450,000$ damages under the Sherman Act does not merit discussion here. Tepler v. Frick et al., CCH TRADE REG. REp. ๆ 67, 331 (S.D.N.Y. Aug. 28, 1952). Tepler claimed that he injured his arm while pitching for Nashville in 1944 and that the defendants, through the rules and regulations of organized baseball, reduced him to the status of a chattel and were negligent in their care of him. Stated Judge Edelstein in dismissing the complaint: "While there is a detailed description of a monopolistic system which, it is said, reduces a baseball player to a status of peonage, the closest scrutiny of the complaint does not disclose what acts these defendants performed in violation of the antitrust laws to the injury of the plaintiff. Actually, what seems to be alleged is that the defendants are part of a monopoly and that they took action to the injury of the plaintiff. However, I do not find the necessary allegation of damage to the plaintiff resulting proximately from the acts of the defendant which constitute violation of the antitrust laws." Id. at p. 67,796 . The correctness of this position is incontrovertible. Baseball players are not peons, Augusta Baseball Ass'n v. Thomasville Baseball Clúb, 147 Ga. 201, 202-03, 93 S.E. 208 (1917); and the antitrust laws provide no remedy for damages unrelated to restraints of competition in the market. Apex Hosiery Co. v. Leader, 310 U.S. 469 (1940).

166. Toolson v. New York Yankees, Inc. et. al., 101 F. Supp. 93 (S.D. Cal. 1051), aff'd per curiam, 200 F.2d 198 (9th Cir. 1952); Corbett and E1 Paso Baseball Club, Inc. v. Chandler et al., No. 2589, S.D. Ohio, Jan. 25, 1952, aff'd, 6th Cir., Feb. 20, 1953; Kowalski v. Chandler et al., No. 2646, S.D. Ohio, Jan. 25, 1952, aff'd, 6th Cir., Feb. 20, 1953.

167. Federal Baseball Club of Baltimore, Inc. v. National League of Professional Base Ball Clubs, 259 U.S. 200, 208-09 (1922). 
The Federal Baseball case stands today, a much-criticized relic of bygone interpretations of the commerce clause. ${ }^{108}$ But it still stands. Until it is overruled or distinguished, it will indefinitely perpetuate organized baseball's intricately-woven monopsony, both as to the combination's economic power and whatever abuses which may arise from the exercise of that power.

The criteria of interstate commerce employed by the Supreme Court in the Federal Baseball case have been obsolete for more than fifteen years. Since 1937 the Supreme Court, reaffirming the broad doctrine of Gibbons $\because$ Ogden, ${ }^{169}$ has repeatedly asserted that any activity which crosses state borders, ${ }^{170}$ any activity which uses the channels of interstate commerce, ${ }^{171}$ or any local activity which even remotely affects other states or interstate commerce ${ }^{172}$ comes within the purview of the commerce power. On at least four occasions the Supreme Court has emphasized that Congress, in enacting the Sherman Act, exercised "all the power it possessed."173 Therefore, tests

168. In the Gardclla case, Judge Frank characterized the Foderal Bascball cace as an "impotent zombi." In his view, the Supreme Court "has overruled the precedents upon which that decision was based," and further "the cuncept of commerce has changed enough in the last two decades so that if that case were before the Supreme Court de novo, it seems very likely that the Court would decide the other way." Gardella v. Chandler, 172 F.2d 402, 409 n.1 (2d Cir. 1949) (concurring upinion). Judge Goddard seemed quite reluctant to follow the 1922 decision when he confronted the Gardclla case in the district courts. 79 F. Supp. 260 (S.D.N.Y. 1948). See also Toplis, Mronopoly in Professional Sports, 58 Yale L.J. 691 (1949) : Neville, Bastiall and the Antitrust Lous, 16 FORD L. REv. 208 (1947) ; Note, 5 INrRuMcRul L. Rev. (N.Y.U.) 206 (1950).

169. 9 Wheat 1 (U.S. 1824). The power to regulate commerce among the states, "like all others vested in congress, is complete in itself, may be exercised to its utmost extent, and acknowledges no limitations, other than are prescribed in the constitution.... The wisdom and the discretion of congress, their identity with the people, and the influence which their constituents possess at elections, are, in this, as in many other instances, as that, for example, of declaring war, the sole restraints on which they have relied to secure them from its abuse. . . Commerce, undoubtedly, is traffic [i.e, trade in commodities], but it is something more-it is intercourse. It describes the commercial intercourse between nations, and parts of nations, in all its branches. . . Comprehensive as the word 'among' is, it may very properly be restricted to that commerce which concerns more states than one. ..." Id. at 196, 197, 189-90, 194.

170. United States v. South-Eastern Underwriters Ass'n, 322 U.S. 533 (1944); Polish National Alliance v. NLRB, 322 U.S. 643 (1944).

171. North American Co. v. SEC, 327 U.S. 686 (1946); Associated Press v. United States, 326 U.S. 1 (1945); Associated Press v. NLRB, 301 U.S. 103 (1937).

172. Mandeville Island Farms v. American Crystal Sugar Co., 334 U.S. 219 (1948); Wickard v. Filburn, 317 U.S. 111 (1942); Kirschbaum Co. v. Walling, 316 U.S. 517 (1942) ; United States v. Darby, 312 U.S. 100 (1941); United States v. Roel: Royal Co-operative, 307 U.S. 533 (1939).

173. Atlantic Cleaners \& Dyers, Inc. v. United States, 286 U.S. 427, 435 (1932); Apex Hosiery Co. v. Leader, 310 U.S. 469, 495 (1940); United States v. Suuth-Eastern Underwriters Ass'n, 322 U.S. 533, 558 (1944); United States v. Franlfort Distilleries, 324 U.S. 293, 298 (1945). "The addition of the words "or commerce among the several States' [to the Sherman Act] . . . was the means used to reinte the pruhititcd restraint of trade to interstate commerce for constitutional purposes ... so that Congress, through 
of "direct" or "indirect" effects on interstate commerce, or the amount of interstate business activity involved, if any, become irrelevant. ${ }^{174}$

Application of present-day tests to the facts revealed by the recent congressional investigation would indicate that organized baseball is unquestionably an interstate activity. The business combination encompasses practically every state in the union and, indeed, many foreign countries as well. While the final exhibition which the consumer buys is a local affair, as in motion picture exhibitions, operas, and other spectator amusements, interstate commerce is a necessary component of presenting such exhibitions. Every spring, professional baseball clubs train for the championship season in the South and present "barnstorming" exhibitions at whistle-stops along the way. The championship season itself requires clubs to abide by a fixed schedule, neces* sitating interstate transportation of both players and essential paraphernalia. Players sign annual contracts which bind them to appear in every state where the club has scheduled games. Negotiations for these contracts are usually made across state lines, and the contracts themselves, being both assignable and renewable under "baseball law," are articles of commerce which are bought, sold, and bartered in interstate transactions. And finally, because of the interdependence of baseball clubs blanketing the entire nation, the industry is not amenable to effective state regulation. ${ }^{\mathbf{1 7 5}}$

The situation before the Court in the Federal Baseball case may also be distinguishable from present conditions on two grounds. The increased commercialization of baseball through radio and television, plus additional restraints on players caused by the farm system, render organized baseball quite different today from thirty years ago. Either or both of these factors might be held to impress an interstate character on the business even under the obsolete Federal Baseball rationale. 176 The combination's monopsonistic agreements affect the sale of radio and television rights, a market which accounts for about fifteen percent of major league revenue. Furthermore, the stbstitution of the farm system for the universal draft has retarded the interstate movement of players to better-paying clubs as their abilities warrant.

its commerce power, might suppress and penalize restraints on the competitive system which involved or affected interstate commerce. . . . It was in this sense of preventing restraints on commercial competition that Congress exercised 'all the power it possesscd." " Apex Hosiery Co. v. Leader, 310 U.S. 469, 495 (1940) (emphasis added).

174. Mandeville Island Farms v. American Crystal Sugar Co., 334 U.S. 219, 236 (1948); Mabee v. White Plains Pub. Co., 327 U.S. 178 (1946); Wickard v. Filburn, 317 U.S. 111, 124-5 (1942); United States v. Darby, 312 U.S. 100, 123 (1941). "And the amount of interstate or foreign trade involved is not material . . . since $\S 1$ of the Act brands as illegal the character of the restraint, not the amount of commerce affected." United States v. Socony-Vacuum Oil Co., 310 U.S. 150, 224 n.59 (1940).

175. See House RePort, 4-7.

176. See Note, 5 Intramural L. Rev. (N.Y.U.) 206, 215-16 (1950). Judges Learned Hand and Frank relied upon the radio and television features of organized baseball to distinguish Federal Baseball in the Gardella case, 172 F.2d 402, 404, 415 (2d Cir. 1949). 
Professional baseball is not only interstatc but also "trade or commerce" within the meaning of the Sherman Act. The illusory distinction, urged by organized baseball and adopted by the sixth and ninth circuit courts, that professional baseball is sport and not trade or commerce, ${ }^{177}$ finds no support in recent Supreme Court decisions. The fact that professional baseball is a sport in no manner detracts from the fact that it is also a business. Neither the commerce clause nor the Sherman Act are limited to businesses dealing in commodities. Enterprises dealing in services are likewise trade whether they sell real estate brokerage, ${ }^{178}$ medical, ${ }^{179}$ dry cleaning, ${ }^{180}$ or entertainment services. ${ }^{181}$ Any doubts as to the Sherman Act covering service industries were finally dispelled by United States v. National Association of Real Estate Boards, ${ }^{182}$ which endorsed Justice Story's oft-quoted definition of trade, made in 1834 :

"Wherever any occupation, employment, or business is carried on for the purpose of profit or gain or a livelihood, not in the liberal arts or in the learned professions, it is constantly called a trade."183

177. Corbett and El Paso Baseball Club, Inc. v. Chandler ct al., th Cir., Feb. 20, 1953; Kowalski v. Chandler et al., 6th Cir., Feb. 20, 1953; Toolson v. New Yorls Yanlees, Inc. et al., 200 F.d 198 (9th Cir. 1952), affirming 101 F. Supp. 93 , 94 (S.D. Cal. 1951); Brief for Appellees, pp. 10-1t, Toolson v. New York Yankees, Inc., 200 F21 108 (9th Cir. 1952); Brief for Appellees, pp. 10-14, Corbett and El Paso Baseball Club, Inc v. Chandler, 6th Cir., Feb. 20, 1953; Erief for Appellees, ip. 1t-18, Kowalski v. Chandler cl al., 6th Cir., Feb. 20, 1953. See also Eckler, Baseball-Sport or Commerce?, 17 U. of Crir. L. REv. 56, 65-S (1949). The source of this maxim is the Circuit Court holding in the Federol Baseball case. Judge Smyth there asserted that the business of giving baseball exhibitions "effects no exchange of things," and therefore, "The act is not trade or commerco-it is sgort. The fact that the appellants produce baseball games as a source of profit, large or small, can not change the character of the game They are still sport, not trade." National League v. Professional Baseball Club of Baltimore, Inc, 269 Fed. 681, 684-5 (D.C. Cir. 1920).

178. United States v. National Ass'n of Real Estate Eoards, 339 U.S. 485 (1950).

179. American Medical Ass'n v. United States, 317 U.S. 519 (1943).

180. Atlantic Cleaners \& Dyers v. United States, 286 U.S. 427 (1932).

181. Ring v. Spina, 148 F.2d 647, 650, 651 (2d Cir. 1945) ; Marienelli, Ltd. v. United Booking Offices of America, 227 Fed. 165 (S.D.N.Y. 1914). Sce also Lorain Journal v. United States, 342 U.S. 143 (1951) (newspaper advertising); Charles A. Ramsay Co. v. Associated Bill Posters, 260 U.S. 501 (1922) (billboard advertising); United States v. General Motors Corp., 121 F.2d 376 (7th Cir. 1941) (automobile financing); United States v. Local Union No. 639, 32 F. Supp. 594 (D.D.C. 1940) (building construction); United States v. South-Eastern Underwriters Ass'n, 322 U.S. 533 (1944) (insurance); Associated Press v. United States, 326 U.S. 1 (19.45) (news services); United States v. Pullman Co., 50 F. Supp. 123 (E.D. Pa. 1943), aff'd (by an equally divided court), 330 U.S. 806 (1947) (pullman services); United States v. Northern Securities Co., 193 U.S. 197 (1904) (railroad services); United States v. Yellow Cab Co., 332 U.S. 218 (1947) (taxi services); Anderson v. Shipowners' Ass'n of Pacific Cosst, 272 U.S. 359 (1926) (shipiping services) ; Mercer v. United States, 61 F.2d 97 (3d Cir. 1932) (tructing services).

182. 339 U.S. 485 (1950).

183. Id. at 490-1, quoting The Schooner Nymph, 1S Fed. Cas. No. 10,3ss, at 507 (C.C.D. Me. 1834). 
Despite the obsolescence of the legal doctrines in the Federal Bascball case, ${ }^{\mathbf{1 8 4}}$ the courts may be tempted to reaffirm it on policy considerations. Senator George Wharton Pepper, who represented organized baseball in its successful fight for antitrust immunity thirty years ago, used essentially a

184. This obsolescence is perhaps best demonstrated by comparison of the language of the Federal Baseball case with more recent Supreme Court decisions:

"The business is giving exhibitions of baseball, which are purely state affairs." Federal Baseball Club of Baltimore, Inc. v. National League, 259 U.S. 200, 209 (1922).

"It is true that in order to attain for these exhibitions the great popularity that they have achieved, competitions must be arranged between clubs from different cities and States. But the fact that in order to give the exhibitions the Leagues must induce free persons to cross state lines and must arrange and pay for their doing so is not enough to change the character of the business." Id. at 208-9.

"According to the distinction insisted upon in Hooper v. California, 155 U.S. 648, $655, \ldots$ the transport is mere incident, not the essential thing." Id. at 209.

"That to which it is incident, the exhibition, although made for money would not be called trade or commerce in the commonly accepted use of those words. As it is put by the defendant, personal effort, not related to production, is not a subject of commerce." Ibid.
"The showing of motion pictures is of course a local affair. But ... the course of business which involves a regular exchange of films in interstate commerce is adequate to bring the exhibitors within the reach of the Sherman Act." United States v. Crescent Amusement Co., 323 U.S. 173, 183-4 (1944).

"Whatever, was the ultimate object of this conspiracy, the means adopted for its accomplishment reach beyond the boundaries of Colorado." United States v. Frankfort Distilleries, 324 U.S. 293, 298 (1945).

(In holding the Hooper case inapposite to the Sherman Act:) "In short, a nationwide business is not deprived of its interstate character merely because it is built upon sales contracts which are local in nature. Were the rule otherwise, few businesses could be said to be cngaged in interstate commerce." United States v. South-Eastern Underwriters Ass'n, 322 U.S. 533,547 (1944).

"[T]here is an obvious distinction to be drawn between a course of conduct wholly within a state and conduct which is an inseparable element of a larger program dependent for its success upon activity which affects commerce between tho states." United States v. Frankfort Distilleries, supra, at 297.

"Whatever other meaning 'commerce' may have included in 1787, the dictionaries, encyclopedias, and other books of the period show that it included trade: business in which persons bought and sold, bargained and contracted. And this meaning has persisted to modern times." United States v. South-Eastern Underwriters Ass'n, supra, at 549. 
policy approach. In his argument before the Supreme Court, April 19, 1922, the eve of the playing season, he claimed that the very existence of the national pastime, from the Class D leagues to the World Series, was at stalie. He asserted that the Sherman Act should apply only to businesses which might be conducted with or without restraints because the Act was based on the economic theory that separate, competitive production, in the long run, resulted in greater public advantage-through lower prices and better products-than where monopoly or combinations existed. This theory, he claimed, collapsed when applied to professional sports such as baseball. ${ }^{185}$

Today, defenders of organized baseball are following the same line of argument. They contend that baseball, like other team sports, faces problems unique in the realm of business; that the sport demands restraints on economic competition if it is to survive as an amusement industry; and implicitly that the industry merits special consideration under the antitrust laws. ${ }^{180}$ The assertion that professional basebail is "sport not commerce" appears to be one manifestation of this approach.

Even assuming the accuracy of this premise. re-endorsement of the Fcderal Baseball case on policy grounds contains two fatal errors. It would grant carte blanche immunity to all restraints on competition in professional baseball, whether or not they arose from the unique character of the industry. It would also be a clear usurpation of the policy-making function of Congress, a committee of which declared in May, 1952, that the sport warranted no absolute immunity from the antitrust laws. ${ }^{187}$

Even if the Federal Bascball case should be overruled or distinguished, organized baseball contends that monopsonistic restraints involving employment services as distinguished from monopolistic restraints in marketing consumer's services are not "restraints of trade" within the meaning of the Sherman Act. The industry claims that the antitrust laws were enacted solely in the interest of the public as consumers and hence proscribed only those restraints which tended to raise the price of services sold to the consuming public. It further contends that Section 6 of the Clayton Act, ${ }^{18 s}$ properly construed, declares that employers' monopsony agreements are not prohibited restraints

185. Brief for Respondent, Passim. Fodcral Basclall case, 259 U.S. 200 (1922). Chief Justice Taft, who joined in the unanimous opinion of the Supreme Court, had tren approached by organized baseball in 1918 to become the first commissioner. He announced his availability for the post, but the American League balked at the plan and he was never named. House RePORT, 58.

186. "As appellees view it, the very existence of professional baseball in this country, at least along the lines upon which it has been conducted during the last three quarters of a century, is at stake. If the appellant can successfully maintain his present action, the continued conduct of the sport will be seriously imperiled, to the detriment of the public, the baseball leagues and clubs, and the thousands of professional baseball players." Brief for Appellees, p. 5, Toolson v. New York Yankees, Inc, 200 F.2d 198 (9th Cir. 1952). See also id. at p. 17.

187. House REPORT, 230-1.

18\$. 15 U.S.C. $\$ 17$ (1946). 
of trade. And it finally claims that player grievances against their employers' monopsony agreements arise from "labor disputes" and therefore, by Section 20 of the Clayton Act ${ }^{189}$ and the Norris-LaGuardia Act, ${ }^{100}$ that relief under the Sherman Act is prohibited.101

A literal reading of the labor amendments to the Sherman Act contained in the Clayton and Norris-LaGuardia acts offers some support to this position. Section 6 of the Clayton Act opens with the declaration "that the labor of a human being is not a commodity or article of commerce."102 Section 20 of the same act reads in part:

"No restraining order or injunction shall be granted ... . in any case ... between employers and employees ... involving, or growing out of, a dispute concerning terms or conditions of employment. . . .

"And no such restraining order or injunction shall prohibit any person or persons, whether singly or in concert . . . from ceasing to patronize or to employ any party to such dispute, or from recommending, advising, or persuading others by peaceful and lawful means so to do; . . . nor shall any of the acts specified in this paragraph be considered or held to be violations of any laze of the Unitcd States."193

The Norris-LaGuardia Act precludes injunctive relief for certain specified acts in any case involving or growing out of any labor dispute. 104 "Labor disputes" are defined as "any controversy concerning terms or conditions of employment . . . between one or more employers or associations of employers and one or more employees ... regardless of whether or not the disputants stand in the proximate relation of employer and employee."105 In construing these labor provisions, the Supreme Court has declared that the Sherman Act, Section 20 of the Clayton Act, and the Norris-LaGuardia Act are three interlacing statutes which are to be read together. The broader definition of

189. 38 STAT. 738 (1914), 29 U.S.C. \& 52 (1946).

190. 47 Stat. 70 (1932), 29 U.S.C. \$ 101 (1946).

191. Brief for Appellees, pp. 43-63, Toolson v. New York Yankees, Inc, 200 F.2d 198 (9th Cir. 1952); Brief for Appellees, pp. 35-39, Corbett and El Paso Baseball Club, Inc. v. Chandler, 6th Cir., Feb. 20, 1953; Brief for Appellees, pp. 21-6, 39-47, Kowalski v. Chandler, 6th Cir., Feb. 20, 1953. These arguments rely principally upon language appearing in Apex Hosiery Co. v. Leader, 310 U.S. 469, 495-7, 502-03 (1940), and cited in several lower court opinions, including Schatte v. International Alliance, 182 F.2d 158, 167 (9th Cir. 1950) ; Conference of Studio Unions v. Loew's, Inc., 193 F.2d 51 (9th Cir. 1951) ; United States v. Gold, 115 F.2d 236, 238 (2d Cir. 1940) ; United States v. San Francisco Electrical Contractors Ass'n, 57 F. Supp. 57, 60-3. (N.D. Cal. 1944). Unlike the situation in organized baseball, all of these cases arose out of labor union activity.

192. 15 U.S.C. $\$ 17$ (1946).

193. 38 Stat. 738 (1914), 29 U.S.C. § 52 (1946) (emphasis added).

194. 47 STAT. 70 (1932), 29 U.S.C. $\$ 104$ (1946).

195. 47 Stat. 73 (1932), 29 U.S.C. $\S \S 113(a), 113(c)$ (1946). 
"Iabor dispute" under the Norris-LaGuardia Act, therefore, is applicable in construing Section 20 of the Clayton Act. ${ }^{196}$

The contention of organized baseball, if upheld, would give all corporations antitrust immunity to agree not to compete for workers' services, to suppress wages, and, by blacklisting, to deprive workers of an opportunity to pursue their livelihood. Such a construction of the antitrust laws is unsupported by either the statutory history or the Supreme Court's interpretation of these enactments. Throughout the congressional debates on the Sherman Act, there was not a single voice raised to indicate an intent to exempt employers' restrictive agreements. ${ }^{197}$ In fact, Congress purposely drafted the Sherman Act in familiar common law terms so as to incorporate into federal law the existing concepts of restraint of trade. ${ }^{193}$ Mionopsonistic agreements among employers in a particular trade to fix or depress the price of labor or to interfere with workers' free market opportunities were void at common law as contracts in restraint of trade. ${ }^{193}$ Likewise, concerted action by employers to regulate wages were unlawful criminal or civil conspiracies if their objective was to depress the price of labor below the free market level. Only when workers combined to raise wages artificially were employers privileged to

196. United States v. Hutcheson, 312 U.S. 219, 231-2 (1941).

197. On the contrary, Senator Edmunds, chairman of the committee drafting the final version of the Sherman Act, expressed his opinion on the floor of the Senate that exemption for all labor union activity was unnecessary because the act prohibited combinations of capital which could regulate or depress the price of labor. Benssa:, Laros ANd The Sherrian Acr 25-6 (1930). Berman's conclusion is that Congress intended the act to apply against trusts and not against labor unions. Id. at $\mathbf{5 3}$.

198. See Apex Hosiery Co. v. Leader, 310 U.S. 469, 497-S (1940).

199. The leading case was Hilton v. Eckersley, 6 E. \& B. 47 (Q.B. 1855), of 'd 6 E. \& B. 66 (Ex. 1856), which held a contract among eighteen Lancaster employers in the cotton textile trade to conform to uniform wage, hour, and disciplinary practices for one year to be a restraint of trade. The court asserted that the economic power of employers to depress wages was contrary to public policy, regardless of whether the employces themselves were organized. The Hilton case was followed by Afineral Water Bottle Exchange \& Trade Protection Soc. v. Booth, 36 Ch. D. 465 (1887), which held in restraint of trade a contract among 179 employers agreeing not to hire employees within two years after leaving the service of a competitor.

The Hilton doctrine was recognized as the common law in the United States at the time of the Sherman Act: Huston v. Reutlinger, 91 Ky. 333, 15 S.W. \$67 (1891) (restraint of trade for Louisville employers in insurance trade to agree to limit freedom of employment and to fix wages); People c.x rel. Micllhaney v. Chicago Live Stods Exchange, 170 IIl. 556, 48 N.E. 1062 (1S97). Cf. People cx rel. Gray v. Miedical Society of County of Erie, 24 Barb. Ch. 570 (N.Y. Sup. Ct. 1857). See also Resrutene:it, Cormucrs $\&$ 515(c), Illustrations 20-22 (1933) ; 6 CosBre, CoxtRncrs 556, \$61 (1951). Legal recognition of labor's right to combine led to a modification of this common law doctrine. Where employees combined in unions for the purpose of raising wages, employers treame privileged to combine in associations to the degree necessary to place bargaining power on a parity. See Notes, 25 CoL L. Rer. 647 (1925), 26 COL L. Rer. 344 (1926); and nute 200 infra. To this degree employers' associations may be nermissible under the Sherman Act. 
combine in retaliation. ${ }^{200}$ Blacklisting or boycotting, when it deprived workers of an opportunity to pursue their calling or when it prevented competitors from securing unemployed workers, was also condemned.201

Both federal courts and contemporary commentators early recognized that the Sherman Act applied to employers' activities in restraint of trade.202 Limited only by the scope of the commerce power, ${ }^{203}$ federal courts invoked the Sherman Act against monopsonistic agreements in restraint of trade in the employment market. ${ }^{204}$

Sections 6 and 20 of the Clayton Act resulted from widespread use of the Sherman Act to combat strikes. These sections were intended to remedy court interpretations of the Sherman Act which, in the opinion of Congress, had been unduly severe on combinations of laborers. ${ }^{205}$ Neither the com-

200. "[A]n association is criminal when its object is to depress the price of labour below what it would bring if it were left without artificial excitement by either masters or journeymen to take its chance in the market, [but] . . a combination to resist oppression, not merely supposed but real, would be perfectly innocent; for where the act to be done and the means of accomplishing it are lawful and the object to be attained is meritorious, combination is not conspiracy." Gibson, J., Commonwealth $c x$ rel. Chew v. Carlisle, 1 Bright 36, 42 (Pa. 1821). Cf. Cote v. Murphy, $159 \mathrm{~Pa} .420,430,28$ Atl. 190, 193 (1894): "The combination of the employers . . . was not to interfere with the price of labor as determined by the common law theory, but to defend themselves against a demand made altogether regardless of the price, as regulated by the supply. The element of an unlawful combination to restrain trade because of grced or profit to themselves, or of malice toward plaintiff or others is lacking, and this is the essential element of which are founded all decisions as to common law conspiracy in this class of cases. And however unchanged may be the law as to combination of employers to interfere with wages, where such combinations take the initiative, they certainly do not depress a market price when they combine to resist a combination to artificially advance price."

201. Mattison v. Lake Shore \& M.S. Ry., 3 Ohio Dec. 526 (1895); Blumentha1 v. Shaw, 77 Fed. 954 (3rd Cir. 1897). Problems of proving a conspiracy to blacklist were difficult, however. See, c.g., Bradley v. Pierson, 148 Pa. 502, 24 Atl. 65 (1892).

202. See, e.g., United States v. Addyston Pipe \& Steel Co., 85 Fed. 271, 279, 290 (6th Cir. 1898), citing Hilton v. Eckersley; Stimson, Handiook of Lador Law, 185-6, 205, 222, 337, 339, 346, 347 (1896). See also 6 Corbin, Contracts $\S 1401$ (1951).

203. Federal Baseball case, 259 U.S. 200 (1922); Hart v. B. F. Keith Vaudeville Exchange, 12 F.2d 341 (2d Cir. 1926), cert. denied, 273 U.S. 704 (1927).

204. Marienelli, Ltd. v. United Booking Offices of America, 227 Fed. 165 (S.D.N.Y. 1914) ; Anderson v. Shipowners' Ass'n of Pacific Coast, 272 U.S. 359 (1926). In Anderson's brief to the Supreme Court, he relied heavily upon both the Marienelli and Hillon cases. Brief for Appellant, pp. 26-8, 32-7. The shipowners urged in vain that their agreement was a restraint on employment, not "commerce," and therefore not subject to the Sherman Act. Brief for Respondent Against Granting Certiorari, p. 10; Brief for Respondent, p. 21.

205. "In this pending bill, disguise it as we may, dodge and evade as we may, there is one great question we must meet and settle, and that is the question as to whether this proposed law shall be directed against the combination of capital that the Sherman antitrust law was designed to be directed against or whether the antitrust laws shall be shifted, partially at least and turned as an engine of oppression and destruction 
mittee reports nor the congressional debates reveal any intent to exempt employers' restrictive agreements. In fact, the debates frequently contained condemnations of the power of "trusts" and other combinations of capital to depress the price of labor and exploit the working man. ${ }^{208}$

In Section 6, Congress intended to grant associations of workers and farmers the same right to act collectively which investors enjoyed through the corporate business unit. ${ }^{207}$ The declared policy of this section was to reassert the basic purpose of the Sherman Act, which was directed not against restraints of competition among farmers and workingmen who had nothing to sell but the products of their own labor, but against restraints on competition among firms which bought such services or commodities at depressed prices and sold them in the same or altered form to the consuming public at artificially high prices. ${ }^{20 s}$ Culminating prolonged consideration of this section by both houses, the Senate added the controversial first sentence,

against some of the very people they are designed to protect. ... [T] [Te very law that was intended to be used to curb monopolies and to preserve equality of orpurtunity among the American people has been used as a means of annoying, harassing, vexing, and in many instances oppressing a large number of the very people the makers of the law declared it shuuld not be used against-the laborers." Sen. Ashurst (Ariz.), 51 Co:ic. Rea 13663, 13666 (1914). For similar pronouncements, see 51 id. at 95:0, 9546-7.

206. "What is a monopoly and what is its source of power ty oppress? It is created by welding together all of the industries which produce any article and placing this combination under one control. ... The monopoly being the only employer of the kind of labor required in the production of the article which it alone produces, ean and does say what such labor will be paid as wages. . . The worlman skilled only in malsing the thing sold by the monopoly must accept the wages it offers or do without and try to learn some other business." Rep. Crosser (Ohio), 51 Conic. Kex. 9555 (1914). See also e.g., 51 id. at $9154,9543,9552$.

207. H.R. Rep. No. 627, 63d Cong., 2d Sess. 14-16 (1914); SEx. REP. No. 698, 63d Cong., 2d Sess. 10-12 (1914) ; 51 CoxG. Rec 9086-7, 9165-6, 9171-4, 9249, 9549, 13662-7, 1384t-8, 13509-11, 13918, 14020-1, 14214 (1914).

208. "The only organizations which should be excluded from the operation of the antitrust laws are those where labor is the basis or one of the chief factors in the organization, as in the case of labor organizations proper, and in agricultural and horticultural organizations. The Committee rest this distinction upon the brond ground that labor is not, and ought not to be regarded as, a commodity within the purviev of the antitrust laws." SEN. REP. No. 698, 63d Cong., 2d Sess. 46 (1914). The remarlss of Rep. Barkley (Ky.) were typical of those made on the floor of Congress: "So suecessful have these great combinations of wealth been in the past, not only in their organization but also in their operation, that we are now compelled to buy much that we buy from a trust, and to sell to a trust much that we have to sell. This condition in the past has enabled the trust and monopoly to fix the price of the thing it bought from us and the thing it sold to us, the result being that the real producer and the real consumer have both been at the mercy of these great aggregations of wealth. . . . [Section 6] gives to labor and agriculture what it asks and is entitled to. It recognizes the difference between the man whose only asset is his power to work and the men who seek to use labor and the products of labor for monopolistic purposes." 51 Co:iG. Rec. 9552, 9554 (1914). See also 51 Coxc. Rec y541, 9554, 955t, 9559, 954t, 13667, 14018, 14587 (1914). 
which purportedly clarified this congressional policy: "That the labor of a human being is not a commodity or article of commerce."200

In Section 20, Congress specified the practices which labor unions could employ without violating the antitrust laws or any other federal law. This section incorporated that line of judicial decisions which Congress thought best described the legitimate practices of labor organizations. As both the House and Senate committee reports stated:

"The consensus of judicial view, as expressed in these cases and others which might be cited, is that workingmen may lawfully combine to further their material interests without limit or constraint, and may for that purpose adopt any means or methods which are lawful. It is the enjoyment and exercise of that right and none other that this bill forbids the courts to interfere zeith."210

Congress addressed Section 20 solely to concerted action by labor organizations "concerning terms or conditions of employment."211 The floor manager of the bill in the House of Representatives explained that this section "covers in a proper way, we think, every possible angle of the strike situattion."212 Congress gave no consideration to employers' agreements not to compete, which had nothing to do with the collective bargaining situation. The Senate Judiciary Committee declared that it added the phrase, "whether singly or in concert," merely to ensure the right of workers to act together in pursuing their strike activities. ${ }^{213}$

209. The first sentence was formally proposed as an amendment by Sen. Culberson (Texas), floor manager of the bill in the Senate, 51 Conc. Rec. 14590 (1914), and was adopted by a voice vote, 51 id. at 14591 . Rep. Webb ( $N$. Car.), floor manager in the House, commented: "Of course that is a mere legislative declaration or postulate. I do not think it does any harm. I do not know that it does any good. Your conferees agreed to let it remain." 51 id. at 16276. See also 6 Corbin, Contracts 561 (1951).

210. H.R. Rep. No. 627, 63d Cong., 2d Sess. 32 (1914) ; Sen. Rep. No. 698, 63d Cong., 2d Sess. 30 (1914) (emphasis added).

211. 38 Stat. 738 (1914), 29 U.S.C. $\$ 52$ (1946).

212. 51 Cong. Rec. 9660 (1914). Rep. Webb further explained that the word "others" was confined to the parties to the labor dispute. $51 \mathrm{id}$. at 9652-3. To allay the fears of the AFL that unions' strike activities, immune from attack by injunction, might still lead to treble damage actions, Webb introduced as a committee amendment the final clause of what became $\S 20$. 51 CoNG. REc. 9652 (1914), adopted by voice vote, 51 id. at 9662 .

213. Sen. Rep. No. 698, 63d Cong., 2d Sess. 51 (1914). Both proponents and opponents of the bill as finally worded appeared to recognize that $\$ \$ 6$ and 20 were intended only to bestow favors on organized labor. As Rep. Webb summarized these two sections: "This is a codification of labor's rights, to apply to the whole United States. . . . I think the two sections constitute labor's bill of rights that they have been clamoring for for 25 years; and we have written into the statute law what is considered to be the best opinions of the courts as to labor and labor's rights." 51 ConG. REc. 16279 (1914). Other congressmen echoed these sentiments, including Rep. Floyd (Ark.), who said: "The provisions of the bill relating to labor greatly restrict the power heretofore exercised by big corporations and combinations over laboring men and labor organizations, often by the improper use of injunctions." $51 \mathrm{id}$. at 16321. 
Seventeen years later, Congress again responded to labor's cries of antitrust harassment and passed the Norris-LaGuardia Act "to protect the rights of labor in the same manner as the Congress intended when it enacted the Clayton Act, which act by reason of its construction and application by the Federal courts, is ineffectual to accomplish the congressional intent."21s To remove any doubt as to the construction to be placed on the Norris-LaGuardia Act, Congress included a statement of public policy, described as a refinement of the first sentence of Section 6 of the Clayton Act::15

"Whereas under prevailing economic conditions, developed with the aid of governmental authority for owners of property to organize in the corporate and other forms of ownership association, the individual unorganized worker is commonly helpless to exercise actual liberty of contract and to protect his freedom of labor, and thereby to obtain acceptable terms and conditions of employment, wherefore, though he should be free to decline to associate with his fellows, it is necessary that he have full freedom of association, self-organization, and designation of representatives of his own choosing, to negotiate the terms and conditions of his employment, ... therefore, the following definitions of, and limitations upon, the jurisdiction and authority of the courts of the United States are hereby enacted."216

If employers are in any way exempt from the antitrust laws, it appears clear from this statement of congressional intent that this exemption is limited to activities in the course of collective bargaining. In the Clayton and NorrisLaGuardia acts, Congress has declared that labor unions and employers should be free to bargain concerning terms and conditions of employment without the threat of antitrust harassment. Activities of self-help in such "labor disputes," therefore, are outside the compass of the Sherman Act. But to label organized baseball's player monopsony as an activity arising from a labor dispute seems to be directly contrary to this expressed statement of public policy and unsupported by fact. Blacklisted players are parties to no labor dispute. They are not attempting to reach agreement on terms of employment with their reserving club. On the contrary, they are blaclilisted because they wish to leave their reserving club for employment elsewhere. Furthermore, the uniform player's contract is an employers' contract, framed for and by the club owners without negotiation or even consultation with the players. Under such circumstances disputes "concerning the terms and condition of employment" are patently impossible. The player must accept the uniform contract offered him or be blacklisted.

Finally, there is no unionization in professional baseball and hence no collective bargaining. Every attempt to organize a players' union has been an utter failure, due both to the club owners' monopsony agreements and to the

214. H.R. ReP. No. 669, 72d Cong., 1st Sess. 3 (1931).

215. Id. at 6 .

216. 47 Stat. 70 (1932), 29 U.S.C. $\$ 102$ (1946). 
migratory and seasonal character of the profession.217 The Clayton and Norris-LaGuardia acts, like the common law, ${ }^{218}$ appear to accept the premise that where employees act in concert to bargain collectively, it is reasonable for employers likewise to organize so as to meet them on equal terms. ${ }^{210}$ However, where there is no unionization, the only pretext for such combinations is lacking. Judicial acceptance of the statutory construction urged by organized baseball would leave the unorganized worker without any redress under federal law. The National Labor Relations Act is concerned only with problems related to collective bargaining. ${ }^{220}$ Employees who choose not to unionize, therefore, are restricted to relief under the Sherman Act or no relief at all.

Organized baseball relies principally upon Apex Hosiery Co. v. Leador 221 for support in its contention that the Sherman Act does not apply to restraints involving employment services or "labor competition," as distinguished from "commercial competition."222 In the Apex case, the Supreme Court emphasized that the Sherman Act "was not aimed at policing interstate transportation or movement of goods and property." ${ }^{23}$ "The end sought was the prevention of restraints to free competition in business and commercial transactions." ${ }^{224}$ To the extent the opinion differentiated between "labor competition" and "commercial competition," there is nothing to indicate that such differentiation went beyond recognizing that labor unions under Section 6 of the Clayton Act are not in themselves combinations in restraint of trade. From the point of view of corporations, however, there is no reason for distinguishing competitive restraints in the buying of employment services from restraints in the purchase of any other factor of production. The statutory history of the antitrust laws is void of any such suggestion. And, as the history of organized baseball indicates, commercial monopolies may be perfected as easily by restraints in the labor market as by restraints in any other market. Only where employers form associations for the purpose of facilitating collective bargaining negotiations with labor unions would there appear to be

217. See page 635 and note 296 infra. Since 1946 the major league club owners have solicited the expression of grievances from representatives elected by major league players, but no collective bargaining machinery has been established. The Antitrust Subcommittec described the present system of player representatives as being "of little consequence." HOUSE REPORT, 175-7.

218. See note 199 supra.

219. See, e.g., United States v. San Francisco Electrical Contractors Ass'n, 57 F. Supp. 57, 60-3 (N.D. Cal. 1944).

220. 49 Stat. 452 (1935), 29 U.S.C. $\& 157$ (1946), as amended, 61 Stat. 140 (1947),

29 U.S.C. $\$ 157$ (Supp. 1952).

221. 310 U.S. 469 (1940).

222. See note 191 supra.

223. 310 U.S. 469,490 (1940).

224. Id. at 493. See also id. at 495-7.

225. See id. at 502-3. 
the reasonable type of restraint which the Clayton and Norris-LaGuardia acts exempt from the antitrust laws.926

Viewed in the setting of legislative intent, neither the Clayton Act nor the Norris-LaGuardia Act provide any relief to traditional restraints of trade by: combinations of employers. Whenever these labor provisions have been urged to justify boycotts, blacklists, or other restraints of trade by employers, the Supreme Court has firmly rejected such claims. ${ }^{-27}$ In the Allen Bradlcy case, the Supreme Court declared that the antitrust laws contained two congressional policies: "The one seeks to preserve a competitive business economy; the other to preserve the rights of labor to organize to better its conditions through the agency of collective bargaining." how employers' agreements tending to defeat both of these policies could be held exempted from the Sherman Act. "Seldom, if ever," the Supreme Court noted in the Allen Bradley case, "has it been claimed before, that by permitting labor unions to carry on their own activities, Congress intended completely to abdicate its constitutional power to regulate interstate commerce and to empower interested business groups to shift our society from a competitive to a monopolistic economy."209 What the Supreme Court said in United States $v$. Women's Sportsa'car Manufacturers Association seems equally applicable to organized baseball: the Clayton and Norris-LaGuardia acts "cannot be utilized as a cat's-paw to pull employers' chestnuts out of the antitrust fires." 230

\section{The Merits}

Once the jurisdictional hurdle is mastered, proof of any existing Sherman Act violations should be relatively easy. Most of the agreements of organized baseball and the modes of enforcing such agreements are a matter of public record. The industry operates in a goldfish bowl, with every move of club owners, league officials, Commissioner, and minor league president documented daily in the public press. To prove that the combination violates Section 1 of the Sherman Act, plaintiffs must establish that organized baseball unreasonably restrains competition. ${ }^{231}$ To obtain treble damages or equitable

226. See note 219 sitpra.

227. United States v. Women's Sportswear MIfrs. Ass'n, 336 U.S. 460 (1949); Allen Bradley Co. v. Local Union No. 3, 325 U.S. 797 (1945). See also United States i. National Ass'n of Window Glass MIfrs., 287 Fed. 228 (N.D. Ohio) (agreement tatween manufacturers of handblown window glass and union, fixing vages and dividing labor market), rev'd on other grounds, 263 U.S. 403 (1923).

223. Allen Bradley Co. v. Local Union No. 3, 325 U.S. 797, 805 (1945).

229. Id. at 810 . "There is . . one line which we can draw with assurance that we follow the congressional purpose. We know that Congress feared the concentrated power of business organizations to dominate markets and prices. It intended to outlaw business monopolies." Id. at $S 11$.

230. 336 U.S. 460,464 (1949).

231. Standard Oil Co. of N.J. v. United States, 221 U.S. 1, 55 (1911). Of course certain policies or practices were recognized-in the Stasdard Oil case and since-as so 
relief, the complaining parties must further show that the restraint has caused injury to them. ${ }^{232}$

Monopsony in the player market. The reserve rule, aptly described as the foundation of organized baseball, appears to fall squarely within the doctrine of United States $v$. Socony Vacunm Oil Co. ${ }^{233}$ This case held that all agrecments to manipulate prices are conclusively unreasonable restraints on competition prohibited by Section 1 of the Sherman Act. "No showing of socalled competitive abuses or evils which these agreements were designed to eliminate or alleviate may be interposed as a defense."234

The reserve rule virtually eliminates competition in the purchase of players' services. Players under contract or reservation may be approached by only one buyer, and if they dislike the terms offered, they are unable to sell their skilled services to anyone else. This agreement not to compete in effect allows each club to set its own prices in the player market.

While most of the price-manipulation cases. including the Socony Vacuum case, involved the purchase ${ }^{235}$ or sale ${ }^{230}$ of commodities rather than services, there is nothing in the history of restraints of trade under the Sherman Act to render the distinction significant. The Sherman Act encompasses those restraints of trade which were void and unenforceable at common law. One of the oldest of these was an agreement which prevented a person from freely

dangerous as to be considered conclusively unreasonable or illegal per sc: price-fixing and division of markets, id. at 65, United States v. Trenton Potteries, 273 U.S. 392, 397402 (1927); boycotts and abuse of patents. Sec United States v. Columbia Steel Co., 334 U.S. $495,522-3$ (1948).

232. 15 U.S.C. $\S 15$ (1946). On the use of the antitrust laws for relief by private parties generally, see Comment, Antitrust Enforcement by Private Partics: Analysis of Development of the Treble Damage Suit, 61 YALE L.J. 1010 (1952).

233. 310 U.S. 150 (1940).

234. Id. at 218. Cf. United States v. Trenton Potteries Co., 273 U.S. 392 (1927).

235. See, e.g., Mandeville Island Farms v. American Crystal Sugar Co., 334 U.S. 219 (1948); United States v. Socony-Vacuun Oil Co., 310 U.S. 150 (1940); United States v. Ozark Canners Ass'n, 51 F. Supp. 150 (W.D. Ark. 1943). But cf. Apex Hosiery Co. v. Leader, 310 U.S. 469, 493 (1940): "The end sought [by the Sherman Act] was the prevention of restraints to free competition in business and commercial transactions which tended to restrict production, raise prices or otherwise control the market to the detriment of purchasers or consumers of goods and services, all of which had come to be regarded as a special form of public injury." Implications of this dictum that the Sherman Act applied only to restraints of a monopolistic nature were squelched in the Mandeville case, supra, at 236: "The statute does not confine its protection to consumers, or to purchasers, or to competitors, or to sellers. Nor does it immunize the outlawed acts because they are done by any one of these." The original draft of $\S 6$ of the Clayton Act included an antitrust exemption for consumers' associations. "Consumers" was stricken from the bill by the Senate Judiciary Committee because it "is susceptible of much abuse if in the unrestricted sense it is applied . . . to all character of consumers, including corporations generally." SEx. REp. No. 698, 63d Cong., 2d Sess. 46 (1914).

236. See, e.g., Kiefer-Stewart Co. v. Joseph E. Seagram \& Sons, Inc., 340 U.S. 211 (1951) ; United States v. Frankfort Distilleries, Inc., 324 U.S. 293 (1945); United States v. Trenton Potteries Co., 273 U.S. 392 (1927). 
exercising his calling. ${ }^{237}$ One variety of this common law restraint of trade was an agreement among competing employers to fix prices and other terms of employment.238 That the Sherman Act encompassed such monopsonistic agreements became clear in both the Maricnclli and Anderson cases. ${ }^{200}$ The latter involved a combination of Pacific Coast shipowners which allegedly fixed the wages of seamen, assigned them to particular vessels, and blacklisted those who did not comply with the association's rules. In finding that the complaint stated a cause of action, the Supreme Court declared: "The purpose of the Sherman Act is . . . to preserve the right of freedom of trade. ... [T] he effect of the combination now under consideration, both as to the seamen and the owners, is precisely what [the Act] condemns."

The original purpose of the reserve rule was to reduce player salaries, and that has been its necessary effect. Even though the agreement be considered

237. Opinion of Learned Hand, J., Gardella v. Chandler, 172 F.2d 402, 408 (1949). In the Dyer's Case, Y.B. 2 Hen. V, f. 5, pl. 26 (1415), an empluyment cuntract, in which defendant dyer agreed not to exercise his calling within the plaintiff's town for six months, was held void as a restraint of trade. Commented the court: "And, jer Dieu, if the plaintiff were here he should go to prison until he paid a fine to the King." Sce also anonymous case, Moore 115, 72 Eng. Rep. 476 (K.B. 1575), hulding in rc traint of trads an agreement by an apprentice not to employ his craft in Nottingham for four years. The "rule of reason" was introduced by Mitchel v. Reynolds, 1 P. Wms. 181, 24 Eng. Reg. 347 (Ch. 1711). Voluntary restraints, when ancillary to contraets of employmunt or the sale of a business, were valid if the restraint was reasonable, i.e., if the restraint on the empluyee's or seller's freedom of trade was no broader in scope, both as to time and area, than was reasonably necessary for the protection of the employer or purchaser. Where the voluntary restraint was general, or if the restraint was involuntary (i.e., restraincd frecdom of trade of one not a party to the agreement), the contract was conclusively void. Sce United States v. Addyston Pipe \& Steel Co., 85 Fcd. 271 (6'th Cir. 1898); Hastidier. Cases and Misterials on Trade Regulation 146-91 (1951); o Condi:, Coninucts $\$ \S$ 1383, 1394 (1951) ; Carpenter, Validity of Contrats Not to Compcle, 76 U. of P.. L. REv. 244, 266-71 (1928). Some states have statutes eliminating application of the rule of reason to agreements not to compete which are ancillary to personal service contracts. Such statutes declare that: "Every contract by which one is restrained from esercising a lawful profession, trade or business of any kind . . . is void," except where ancillary to the sale of a business or the dissolution of a partnership. Note, 3 A.L.R.2d 522 (1948). Organized baseball has effectively by-passed these common law and statutory prohibitions on employment contracts in restraint of trade by relying upon its own extra-judicial enforcement of both the covenant not to compete and the reserve clause in the uniform player contract.

238. See notes 199,200 supra.

239. Mfarienelli, Ltd. v. United Booking Offices of America, 227 Fed. 165 (S.D.N.Y. 1914) (attempt to monopsonize vaudeville stars" services by booking companies) ("The necessary inference is that the defendants, if successful, will control all "first class" performers and succeed in monopolizing the supply. This, in turn, enables them to control the whole business, and constitutes the very conditions which the Sherman Act means to prevent." L. Hand, J., id. at 171.) ; Anderson v. Shipowners' Ass'n of Pacific Cosst, 272 U.S. 359 (1926) (monopsony of seamen's services by shipowners).

240. Id. at 363 . 
essential for the survival of the baseball industry, or players' salaries be considered fair and reasonable, the fact that the reserve rule permits prices for services to be manipulated is enough to render the agreement illegal por se. Whatever may be the peculiar problems and characteristics of organized baseball, the Sherman Act, so far as price-manipulation agreements are concerned, "establishes one uniform rule applicable to all industries alike."241

If the reserve rule falls, its instruments of enforcement will fall with it as methods pursued to accomplish an unlawful object. The uniform player contracts containing the reserve clause, being "the result of a concerted plan or plot ... to suppress competition. ... would come plainly within the terms of the statute, and, as parts of the scheme or plot, would be unlawful." "242 Similarly, the blacklisting of recalcitrant players and the boycotting of "outlaw" clubs appear to be illegal per se, and no showing of reasonableness or economic necessity could save such practices if challenged. ${ }^{243}$

Even if the reserve rule were held lawful as a "reasonable" restraint on competition and even if contract-jumping or reserve-jumping were actionable at state law, the boycott and blacklist would appear to remain a per so violation of the Sherman Act. However laudable the purpose of industrial selfregulation, the Supreme Court has held that the ends do not justify the use of such illegal means as a boycott or blacklist. ${ }^{244}$ Neither do the courts concone extra-judicial action by an industry against trade abuses. The Fashion Originators Guild, for example, was found to be an unlawful combination because it was:

"an extra-governmental agency, which precribes rules for the regulation and restraint of interstate commerce, and provides extrajudicial tribunals for determination and punishment of violations, and thus trenches upon the power of the national legislature and violates the statute." 245

241. United States v. Socony-Vacuum Oil Co., 310 U.S. 150, 222 (1940). "[M]arket manipulation in its various manifestations is implicitly an artificial stimulus applied to (or at times a brake on) market prices, a force which distorts those prices, a factor which prevents the determination of those prices by free competition alonc." Id. at 223. "The price-fixing of services was found to be illegal per se in United States v. National Ass'n of Real Estate Boards, 339 U.S. 485 (1950). See also Ramsay v. Associated Bill Posters, 260 U.S. 501 (1923); Ring v. Spina, 148 F.2d 647 (2d Cir. 1945).

242. United States v. Reading Co., 226 U.S. 324, 357-8 (1912). See also Paramount Famous Lasky Corp. v. United States, 282 U.S. 30 (1930) (agreement, among ten competing motion picture distributors, to refuse to license their films except by uniform con* tract which included provisions for boycott of contract violators).

243. Fashion Originators' Guild of America, Ine. v. FTC, 312 U.S. 457 (1941) Anderson v. Shipowners' Ass'n of Pacific Coast, 272 U.S. 359 (1926); Eastern Retail Lumber Ass'n v. United States, 234 U.S. 600 (1914).

244. Fashions Originators' Guild of America, Inc. v. FTC, 312 U.S. 457, 468 (1941); Sugar Institute, Inc. v. United States, 297 U.S. 553, 599 (1936). See also United States v. Columbia Steel Co., 334 U.S. 495, 522-3 (1948).

245. Fashion Originators' Guild of America, Inc. v. FTC, 312 U.S. 457, $465-6$ (1941). 
Vertical integration. If the reserve rule and its enforcement methodsuniform contracts, boycotts, and blacklists-presently violate the Sherman Act, the farm system, which depends upon these practices, will share the same fate. However, even if the reserve rule were exempted under the present labor provisions or a new statute, the further possibility arises that the farm system itself may violate the antitrust laws. Vertical integration is not illegal per se under the Sherman and Clayton Acts. However, when it unreasonally narrows the outlets to which some can sell and the sources from which others can buy, it becomes suspect. ${ }^{240}$ The Supreme Court has indicated that vertical integration or an exclusive dealing arrangement is illegal (1) whenever it is a calculated scheme to gain control over an appreciable segment of the marliet and to restrain or suppress competition, rather than an expansion to meet legitimate business needs; (2) whenever it results in a monopoly which has the power to exclude competition and the ability to exercise leverage on the market; or (3) whenever the effect is to restrict unreasonably the opportunity of competitors to market their products or buy their raw materials. ${ }^{247}$

Each purchase of a minor league subsidiary, each working agreement with a minor league club, narrows the market for the industry's most essential factor of production-player contracts. The farm system grooves the player's opportunity for advancement, enabling the parent club to put major league prospects in deep freeze in the minor leagues for at least seven years without risking loss of the player to a competing club. By controlling the sources of player contracts in the minor leagues, some farm operators have been able to corner the best in playing talent in their own leagues-notably the St. Louis Cardinals, New York Yankees, and Brooklyn Dodgers. Clubs unable to afford large farm systems have been doomed to mediocre teams, poor patronage, and meager or non-existent profits.

More critical, however, is the effect on the players themselves. There may be no overriding public interest in the speed with which an inanimate object such as a motion picture reel reaches exhibitors with the videst public market. But such is not true with player contracts. A player's active career is short, seldom more than ten or fifteen years and hardly ever more than twenty. Years wasted in poor-paying minor leagues mean income forever lost for the player with major league ability. The major league clubs, through their exclusive dealing arrangements with minor league affiliates, are able to channel the sale of player contracts directly to themselves, foreclosing any access to this market by major league competitors. The effect of this leverage in the marketing of player contracts is to retard the promotion of many talented players and thereby deprive them of earnings they could otherwise obtain by performing for a rival major league club.

246. United States v. Yellow Cab Co., 332 U.S. 218, 226-7 (1947).

247. United States v. Paramount Pictures, Inc, 334 U.S. 131, 174 (1949); United States v. Columbia Steel Co., 334 U.S. 495, 524 (1948). 
Division of consumer markets. "Territorial rights"-or the allocation of consumer markets among clubs in organized baseball-appears to be a clear violation of the Sherman Act. Some of the first antitrust cases ever to reach the Supreme Court recognized that such agreements restrained competition and tended to enhance prices to the public. ${ }^{248}$ Organized baseball is no exception. Admission prices through the years typify the behavior of monopolistic industries by their rigidity both in times of depression and inflation. ${ }^{240}$

The most detrimental results of such territory allocation are not the prices charged to the public, however. Competition from other spectator amusements or different forms of recreation prevent the industry from abusing its price pattern. Rather, the chief abuses of "territorial rights" are their effect on the quality of the product, on playing competition among rival clubs, and on the players' salaries. In an industry where equal financial resources have been a prerequisite for equal competitive opportunity, market areas are frozen so as to cause mounting disparity between rival clubs. Clubs fortunate enough to be frozen in the larger markets tend to become stronger with each successive year, to the benefit of their fans, stockholders, and players. Clubs located in the smaller cities, however, are doomed to deteriorating teams and declining attendance, profits, and player salaries.

Exclusion of competitors. The restrictive practices of organized baseball, viewed together, would also appear to monopolize the industry in violation of Section 2 of the Sherman Act. The tactics employed by the combination to exclude competitors are typical of those found in many early Section 2 cases. ${ }^{250}$ The most significant are boycotts and price wars-both designed to prevent access to the player market by outsiders and to preserve the exhibition monopoly.

Even without these predatory practices, however, it would appear that organized baseball is an unlawful monopoly. The legality or illegality of an industrial combination does not depend on whether it is a "good" or a "bad" monopoly. Rather it depends on the economic power of the combination. Where a single corporation or a combination of firms acting in concert so dominates a market as to be able to fix prices or exclude competitors, the requisite intent to monopolize is inferred. ${ }^{251}$ The combination of clubs comprising organized baseball exercises arbitrary control over both the purchase and resale of players' services. By the reserve rule, each club possesses monopsonistic power to fix the price it pays for the services of players who produce baseball exhibitions. By virtue of the leverage provided by this control over the player market, the combination also exercises exclusive control in the market of selling professional baseball exhibitions.

248. See, e.g., Addyston Pipe \& Steel Co. v. United States, 175 U.S. 211 (1899).

249. House Report, 97-8.

250. Standard Oil Co. of N.J. v. United States, 221 U.S. 1 (1911); United States v. American Tobacco Co., 221 U.S. 106 (1911).

251. United States v. Paramount Pictures, Inc., 334 U.S. 131, 173 (1948); American Tobacco Co. v. United States, 328 U.S. 781, 811 (1946); United States v. Aluminum Co. of America, 148 F.2d 416, 431-2 (1945). 


\section{Consequences of Sherman Act Enforcement}

Atomization-or a forced return to free competition-appears probable if present litigation runs its course and if Congress remains inactive. Clubs or players injured by organized baseball's restrictive agreements will be entitled to obtain treble damages and injunctive relief. ${ }^{252}$ Agreements which presently divide player and consumer markets will become void and unenforceable in any court. $^{253}$ To escape recurring suits, organized baseball will have to disorganize. Thus, the entire rubric of competitive restraints binding together the various leagues would disappear-the reserve rule, blacklisting, boycotts, and territorial rights. Only internal league agreements, involving such matters as scheduling games and dividing revenue, would appear safe from antitrust attack, so long as they do not unreasonably restrain competition. ${ }^{204}$ Such atomization is the panacea recommended by many of the game's critics. ${ }^{265}$ However, of present alternatives it is probably the least feasible, for it is a cure that would lill the patient.

A professional team sport faces problems unique in the business world. It is unique because it requires cooperation among competitors in order to produce a marketable product. Its product is competition, requiring for its creation a cooperative association of teams with relatively equal playing ability. Without such competition on the playing field, the public will not buy its product at any price.

Professional baseball is often compared with the motion picture industry, the giant among spectator amusements. True, both Paramount and the Pittsburgh Pirates operate and maintain their own plants and have an exhibition to sell. They both have similar public relations and personnel problems, and both are dependent upon publicity. But the similarity ends there. Paramount may hire its employees, produce and market its films, and choose its most advantageous course of business without the necessity of cooperating with its competitors. Each production is a separate venture, requiring no continuity of performers. The Pittsburgh Pirates, on the other hand, cannot present e:hibitions where and when they please; their product requires competitors to serve as opponents. Neither can they hire whom they please, for their games will be unattended unless their performers have ability comparable to their

252. 15 U.S.C. $\$ \S 15,26$ (1946).

253. 6 Conbrn, Contracts $\$ 13 \& 2$ (1951).

254. Board of Trade of City of Chicago v. United States, 246 U.S. 231 (1918). Where a number of league members boycott another member for the purpose of placing it in a less advantageous competitive position, the rule of reason enunciated by the Chicago Board of Trade case would not appear to save the scheme. See note 136 suspo.

255. See, e.g., Toplis, Montopoly is Professional Sports, 58 YaLE L.J. 691, 705-11 (1949); Moore, The Rescre' Clazlse is Basiball Contracts, 79 Assmses 325 (1943); Ward, Is the Base-ball Player a Chattel?. 40 Lipprocotr's 310 (1837); Hoves Rerusr, $215-20$. 
opponents. Furthermore, they must maintain relative playing equality with their opponents over extended periods of time, because single exhibitions, however closely contested, do not maintain public interest unless they are a part of a larger drama-the quest for a championship.250

Another unique feature in professional baseball is the fact that "psychic income" is as much a motive guiding management decisions as the profit motive. Most investors in the game are businessmen who rely on other industries for financial return. ${ }^{257}$ Most of them are in baseball because they are fans. They want the pleasure which accompanies a championship just as much as their customers. A few major league owners have lost over a million dollars chasing pennants. ${ }^{258}$ Heedless of financial losses, they bid more for player talent than expected gate receipts would warrant just to get a winning team. The presence of one or two such clubs is enough to disrupt an entire market. ${ }^{259}$ Even some of the most profitable clubs have not been operated to reward their investors with dividends. The fabulously successful New York Yankees paid only three dividends in thirty-one years. The two Boston cltibs did not honor their stockholders with as much as a penny for over three decades. ${ }^{260}$

In the face of such considerations, conventional solutions of free or "workable" competition completely break down. Restoration of a free labor market will return the industry to the chaos which ruled in its early years, when clubs had an average life expectancy of two or three years. Early pioneers in the industry tried every available alternative in an attempt to keep the player market open, but nothing short of direct restraints proved capable

256. See HOUSE REPORT, 86-8, 229.

257. HoUSE REPORT, 91.

258. Operating losses for Tom Yawkey's Boston Red Sox totaled two million dollars, 1933-50. The St. Louis Browns cost their owners one million dollars, 1928-39. The Boston Braves lost close to one million dollars during the period, 1923-45. HEAnungs, $1599-1600$. The Braves were reported to have lost a record $\$ 600,000$ during the 1952 season. Sporting News, Nov. 26, 1952, p. 6, col. 1.

259. In the mid-Thirties, Tom Yawkey, owner of the Boston Red Sox, went on a contract-buying spree in an attempt to purchase a pennant-winning team. He spent $\$ 250,000$ for Shortstop Joe Cronin, $\$ 150,000$ for Pitcher Lefty Grove, $\$ 150,000$ for First Baseman Jimmy Foxx, and lesser amounts for other recognized stars. Enough clubs were unwilling to sell, however, so that this aggregation of talent never succeeded in winning a pennant. Sporting News, June 19, 1946, p. 1. Not until Yawkey turned to the farm system and the free market for rookies did the Red Sox reach their goal, in 1946. In one month in 1952, the Red Sox spent about $\$ 100,000$ in cash and promised several times this amount to youngsters who agreed to sign with the Boston farm system. Sporting News, July 2, 1952, p. 1, col. 5. Commented Joe Cronin, now the club's general manager: "[I]t is true that we're all paying more for talent than wo used to. That, of course, is because the kids themselves, operating under the advice of their managers, have got into the habit of playing one bid against another. The thing mushrooms and pretty soon the bidding goes higher than common sense dictates." Sporting News, June 25, 1952, p. 4, col. 2.

260. Hearings, 1600-1. 
of putting the business on a self-paying basis. Championships meant greater prestige and greater revenue, yet only one club could win the championship each year. The annual scramble for players saddled clubs with expenses that only a pennant-winner could hope to meet. To cut the payroll meant a loss of the club's best players, a poor playing record, declining attendance, and certain financial loss. To join in the reckless bidding at best only reduced these losses. For most clubs, the bright hopes of April became disillusionment and deficits by August. Indeed, the number of interested investors and the number of active professional clubs dwindled during the 1870's to the point where a quick demise of the industry seemed probable. .31

Even the players, alleged victims of the reserve rule, generally agree that restraints on their freedom of contract are necessary if the sport is to be a successful business which offers them secure employment. 262 Their criticisms have been directed against the abuses which the reserve rule malies possible - arbitrary salary terms, assignment without consent, blacklisting for joining independent clubs, and the retarding of their advancement to the major leagues. ${ }^{263}$ Elimination of the reserve rule would remove these abuses, it is true. Initially, it might also increase player salaries. But the history of both professional baseball and other professional team sports indicates that the honeymoon would be a brief one. Unless the clubs could eliminate competition in the player market, most investors would soon tire of sceing their savings disappear in the pursuit of player talent and would withdraw from the industry, leaving the players without employment.

Some club owners in former years suggested that the solution was to combine rival clubs in the same league into one corporation. This would permit the league to sign all players and allocate them to member clubs so that pennant races would be evenly contested. Competition for players would exist in leagues bidding against each other for talent. The overriding objection to such a plan has been the fear that it would wreck the public's faith in the integrity of baseball games. When a faction of the National League in 1902 proposed such a reorganization, public disfavor was so pronounced that the plan was scuttled. $^{264}$

261. See House REPORT, 16-22. Even after the formation of organized baseball with monopsony power over the player market, heavy financial losses recurred whenever competition broke out in the industry. During the Players League var (1890) clubs in the National League and independent Players League lost over $\$ 500,000$. Id. at 35. In the first year of the Federal League war (1914), twenty-six clubs in the five largest leagues reported operating losses reaching $\$ 1,250,000$. Id. at 56 . This esperience was duplieated in professional football when the National Football League and the All-America Conference recklessly competed for the services of football players prior to their recent amalgamation. See Topkis, Monopoly in Profossional Sporls, 5S Yule L.J. 691, 704 (1949).

262. HOUSE REPORT, 208-20.

263. Id. at 139-77, 208-20, passint.

264. Id. at 38,41 . See also id. at $\$ 7-8$. 


\section{"Carte Blanche" Exemption}

Inasmuch as professional baseball cannot survive without some kinds of competitive restraints, league and club executives have favored carte blanche exemption from the antitrust laws. Thirty years ago, organized baseball obtained such exemption by Supreme Court edict. ${ }^{205}$ In the last Congress, friends of the sport in both the Senate and House of Representatives proposed bills which would reaffirm what the high court did in 1922 . These bills would exempt all aspects of organized professional sports enterprises from the Sherman Act, Clayton Act, and Federal Trade Commission Act. ${ }^{206}$ The breadth of these bills evoked immediate censure from the Antitrust Subcommittee, to which they were referred. ${ }^{267}$ Not only would they exempt individual professional sports, such as boxing and golf, which have no economic justification for restraints in the performers' market, ${ }^{268}$ but they would also give blanket approval to practices in organized baseball which do not merit special protection. These bills would sanction restrictive broadcasting agreements, the exclusion of new enterprises from the industry, the division of consumer markets, the blacklisting of players who refused to comply with the clubs' own agreements, and any future restraints of trade which the industry might devise. $^{260}$ Although the subcommittee concluded that the preponderance of the evidence established professional baseball's need for "some sort" of reserve rule, ${ }^{270}$ it refused to recommend the full immunity the industry desired. ${ }^{271}$

265. Federal Baseball case, 259 U.S. 200 (1922).

266. House REPORT, 1.

267. See, e.g., Hearings, 382-5.

268. Individual professional sports are exhibited on a match-to-match basis, recuiring no team organization, continuous employment, or cooperation among employers. The promotor can produce the entire exhibition by himself, hiring both or all of the skilled performers necessary for the match.

269. See House Report, 230. The club owners do not appear to be unanimous in their desire for antitrust immunity. P. K. Wrigley, majority stockholder and president of the Chicago Cubs, testified that he personally does not favor complete exemption of organized baseball. Hearings, 734. Even Senator Edwin C. Johnson, who proposed one of the bills for carte blanche exemption, seems to have altered his position. Speaking at the thirtieth annual dinner of the New York baseball writers, in February, 1953, he said: "Last year, when the Celler Committee explored the possibility of monopoly in baseball, [we] made tracks to Washington and filled the record with evidence that there was no monopoly in baseball. We told this committee that baseball was all one bic happy family working together in harmony and understanding to serve America's great public interest in America's great game. We told them that every one in baseball . . . [was] treated fairly and with justice. I can only speak for myself, but if the majors indiscriminately invade the territory of the minors with television as they have with radio, I for one will testify before Congress and the courts that major league baseball is a cruel and heartless monopoly motivated by avarice and greed, and woe unto whoever gets in their path." Sporting News, Feb. 11, 1953, p. 18, col. 1. And see Daley, Cassandra Speaks, N.Y. Times, Feb. 3, 1953, p. 28, col. 6.

270. House REPORT, 229.

271. Id. at 230. 
The wisdom of the Subcommittee's attitude appears obvious. Hovever unique may be the problems of professional baseball, the seventy-year history of organized baseball demonstrates that club owners, acting as they should in their own self-interest, are incapable of providing restraints on their own behavior which would serve as an adequate substitute for the checks of a free market. The only practices in organized baseball which merit exemption from the antitrust laws are those restraints which foster equal playing comprtition among league rivals and thus permit the sport to operate as a business. MIany of the industry's time-honored practices do not accomplish this purpose.

The present leaders of professional baseball inherited the existing pattern of self-regulation from their predecessors. Practices which once were loolied upon as temporary expedients ${ }^{272}$ have now become so engrained that the game's leaders fear losing any one of them would upset the industry. Commissioner Frick, for example, told the Antitrust Subcommittee that "territorial rights" was one of the two foundation stones of professional baseball.:273 Branch Rickey, general manager of the Pittsburgh Pirates, testified that the farm system was the savior of the game. ${ }^{274}$

Such claims lack factual foundation. Neither territorial rights nor the farm system bears any direct relation to the maintenance of playing competition. In fact, under existing conditions, both institutions tend to thwart that goal. Clubs living off the cream of the larger metropolitan areas can afford to buy the contracts of more and better players, hire more and better scouts, and acquire more and better farm clubs, thus tending to create the very unbalanced playing strength which the reserve rule was intended to eliminate. Clubs less favorably situated must accept their fate; the rules sharply restrict their opportunities to move to greener pastures.

The chief beneficiaries of the farm system assert that the minor leagues, training ground for future major league players, could not survive without subsidization from big league clubs..2T5 This may be true, but it is no defense for the status quo. Before vertical integration arose, minor league clubs obtained equivalent subsidization through the prices received from the sale or draft of player contracts. ${ }^{278}$ If this no longer suffices to keep them operating,

272. The first protective barriers around "territorial rights," erected by charter members of the National League in 1876, were "impelled" by the "instinct of preservation" to put the infant industry "on a sound financial and moral basis." Hearmes, 1512-3. The blacklisting of players who ignored organized baseball's monopsony claims and jumped to independent leagues was justified as a temporary "war measure" to destroy the Union Association, "wreckers" of organized baseball. A. G. Mills (president of the National League, 1883-84), Letter to Editor, Sporting Life, Mlay 31, 188\$, original in library, Baseball Hall of Fame, Cooperstown, N.Y. See also House Reforr, 28. According to Branch Rickey, the inception of the farm system "was occasioned by nceessity" to permit a poor club (St. Louis Cardinals) to survive in major league company. Id. at 63 .

273. Heartings, 29; see also House Refort, 150.

274. Id. at 69 .

275. See, e.g., id. at $69-70$.

276. The share of major league receipts used for the subsidization of the minor leagues has remained relatively stable at about ten percent over the past forty years. 
other devices such as direct subsidies taken from major league gate, radio, and television receipts are available to supplement their revenues. ${ }^{277}$

The only major restraint presently used by organized baseball which merits congressional approval is the reserve rule, and then only if adequate safeguards are present. Depriving a professional entertainer of the right to choose his employer is an extraordinary exception to make in an economy which relies on free competition to determine the allocation of human and physical resources. It can be justified only if to do otherwise would destroy the entertainer's livelihood. Moreover, adequate safeguards should be provided which will prevent abuse by baseball employers of their monopsony power. That professional baseball players would eventually lose their occupation without the reserve rule or its equivalent appears clear, both from history and the uncontradicted testimony before the Antitrust Subcommittee. But that players now enjoy safeguards which protect them from the potential abuse of the reserve rule is extremely doubtful. ${ }^{278}$

Essential safeguards for players should at least incorporate those devices, the utility of which organized baseball itself has recognized in the past. These include player limits, minimum salaries, the draft and waiver rules, and the prohibition on farming. Vestiges of all these safeguards still survive, indicating that organized baseball continues at least to render lip-service to their desirability.

No club should be able to control more players than its immediate playing needs require. Organized baseball itself recognized this principle seventyyears ago, ${ }^{279}$ when it first adopted the reserve rule. Player limits assure reserved players of a larger share of the club's revenue and free other players for employment elsewhere. For player replacements, clubs should be able to draft any promising player from clubs in lower leagues or claim through waivers any player released by clubs in their own or higher leagues. Both the draft and waiver rules have been accepted by the industry, in varying

Only the method of subsidization has changed. Forty years ago all of these payments were for the draft or purchase of minor league players' contracts. 'They benefited any minor league club with promising talent. Today most of the payments are to farm clubs, which constitute only 60 percent of minor league clubs. See House REport, 108.

277. Senator Edwin C. Johnson, who doubles as president of the Class " $A$ " Western League, introduced a resolution at the 1952 minor league convention urging the major leagues to devote all of their radio and television receipts for equitable distribution among minor league clubs. Sporting News, Dec. 10, 1952, p. 6, col. 1.

278. See House Report, 139-77.

279. When organized baseball was established in 1883 , each club was limited to the control of eleven players. In the major leagues, this player limit was subsequently increased to twelve in 1885, fourteen in 1887, and thirty-five in 1912; it has been set at forty from 1921 to the present time. Major League Rule 2 presently reads: "Since the supply of skilled players is not equal to the demand, no club shall have title to or under its control at any one time more than 40 players, exclusive of nonplaying manager, coaches, and players who have been promulgated as ineligible or voluntarily retired, or who have been placed on the national defense service and Government lists." House REPORT 152-4. 
degrees, for over half a century.2S0 When universally applied, such rules permit players to work for the highest-paying league warranted by their ability, as determined by the collective judgment of all club managers.

In determining priorities for draft or waiver claims, leagues should be classified according to the salary-paying ability of their member clubs, with leagues in the highest classifications obtaining first preference. $\$ 1$ To promote equal playing competition within each league, draft and waiver priorities should be awarded, as now, to the league members most in need of new talent. ${ }^{252}$ Such league classifications should not be rigid. The door should always be open to new leagues, which would be entitled to the draft and waiver priorities their salary-paying ability warrants. Likewise, existing leagues should be promoted or demoted in the player-preference hierarchy as their financial strength changes, due to population shifts or the shifts of league members to new market areas. The draft and waiver prices should be nominal or abolished altogether, if price is not to become a barrier to a player performing for the highest-paying club which desires his services. ${ }^{2 s 3}$ In addition, players should be free to reject promotion by the draft if they desire to remain with their present employers. ${ }^{24}$ For good cause, they should also be free to reject assignment of their contracts by waivers to a club in a particular locale..$^{235}$

280. The first waiver rule was adopted in 1885 "to keep clubs from sending players to lower or competing leagues without permitting rival clubs to employ such players. Leagues felt it was in their interest to retain a player in that league if any member club desired him. ... Before a club in either major league could assign a player to the other major league or to a minor league club, it had to secure 'waivers' or promises from its competitors not to sign the released player. Through trial and error the National League developed a waiver rule which presumed all clubs waived their claims to a released player unless they indicated to the contrary." House Rerurs, 14t5-\%). If a league rival claimed the released player, it had first option to his services. Subsequently, waivers were required of all major league clubs before players could be transferred to the minor leagues. Similar waiver rules now apply in the higher minor leagues. Ilid.

281. This appears to be the theory of the present rule, which bases classification on the aggregate population of the cities composing each league. National Association Agreement $\$ 10.02$ (b), Hearings, 1195. However, paid attendance, and therefore receipts, have not paralleled population figures. In 1952, for example, the Class " $\mathrm{C}$ " Pioneer League drew more fans than three of the four Class "A" leagues. Natioma Assocthtion of Professional Baseball Leagues, 1952 Highligets 2 (1952).

282. Preference in draft and waiver selections in the major leagues are presently given to clubs in reverse order of their league standing in the pennant race. Major League Rules 5(c), 10(h), Hearings, 1130, 1137.

283. Since the adoption of the draft rules, the maximum drait prices have increased from $\$ 1,000$ to $\$ 15,000$. House RePust, 143-4. In 1907 the majors draited 117 players at an average price of $\$ 1,124$. Hotse REPORT, 145. In 1952 they drafted only eleven at an average price of $\$ 10,909$. Sporting News, Dec. 10, 1952, p. 9, col. 1. The prevailing waiver price in the majors today is \$10,000. Mfajor League Rule $10(\mathrm{k})$, Hearsios, 1137.

284. At times minor league players have preferred to stay with their former clubs rather than be promoted to the major leagues. See, c.g., the cases of Milie Kelley, Kelley v. Herrmann, 155 Fed. S87 (S.D. Ohio 1905), House Rerors, 46-7; and Al Widmar, Hearings, 547.

285. See House REPORT, 167, 169-70. 
Reasonable player limits, a universal draft, and universal waivers would automatically eliminate farm systems and in effect restore the farming ban which once was a part of the baseball code. Ownership of subsidiary clubs could no longer be utilized as a method of engrossing player talent or retarding the advancement of players in their profession.

Although player limits and the draft and waiver rules are still a part of organized baseball's code, numerous exceptions have vitiated their effectiveness. Player limits, which range from twenty-two in the lowest leagues to forty in the majors, are meaningless inasmuch as there is no limit on the number of players which a club may control on farm affiliates. ${ }^{280}$ The draft covers a small fraction of minor league players. Players are ineligible for the draft until they have completed from two to five years of service on minor league clubs. In addition, no more than one player may be drafted from minor league clubs classified as "A" or higher, and players returned to the minors on "option assignments" are ineligible for the draft for an additional three seasons if recalled each fall before the drafting period. ${ }^{287}$ Players may not be claimed on waivers until they have been in the major leagues for three years, and requests are revocable if a competing club claims the contract of the waived player. ${ }^{288}$ In minor leagues classified as " $A$ " or higher, waivers are required only from clubs in the league of the relensing club. In the lower minor leagues, waiver protection is virtually non-existent. ${ }^{289}$ The farming prohibition now applies only to the control of players by secret "gentlemen's agreements," an unnecessary subterfuge today, when clubs can own minor league subsidiaries or enter written working agreements. ${ }^{200}$

Players have frequently agitated for rules which would limit the assignment of their contracts without their consent. ${ }^{291}$ However, the only players having that opportunity today are players with ten years of major league experience whose contract a club wishes to assign to the minor leagues ${ }^{203}$ and Pacific Coast League players who may approve non-draft clatses in their contracts. 293

In addition to the above safeguards, a reasonable code might also provide for minimum salaries, salary arbitration, the drafting of free agents, and the prohibition of player contract sales. Provision for minimum salaries in all classifications, with arbitration of salary disputes between a club and its re-

286. House REPORT, 154-6.

287. Id. at $142-6,158-9$.

288. Major League Rules 10(c), 10(i), Heanings, 1136-7; see House Repokt, 152.

289. National Association Agreement \& 23.02, Hearings, 1215 ; House Rerokt, 147.

290. Major-Minor League Rule 11(k), Hearings, 1168; National Association Agreement § 24.02, Hearings, 1217-8; see House Report, 60, 62-74, 156-9, 177-80.

291. House REPORT, 165-72.

292. Major League Rule 8(b), Major-Minor League Rule 9, Hearrnas, 1134, 1165. This concession for veteran major league players was inserted at the request of the short-lived Ball Players' Fraternity in 1914. House Report, 168.

293. Major-Minor League Rule 5(g), as amended 1951, Hesrings 1180-1. 
served player, would prevent clubs from abusing their discretion in fixing players' salaries. ${ }^{294}$ One danger of the reserve rule is that it tends to siphon club expenditures to the acquisition of new players through the purchase of player contracts or the payment of huge bonuses to promising rookies. If the reserve rule is to accomplish its avowed purpose of equalizing playing competition, it may be desirable to halt these practices by prohibiting the transfer of player contracts except by the draft, waivers, and non-cash trades between clubs of the same classification, ${ }^{205}$ and by extending the draft to rookies entering the profession. These changes would eliminate the present treatment of players as salable chattels and foreclose the opportunity of wealthy clubs to "buy" pennants.

Could these safeguards be achieved by the unionization of ball players? Probably not. Professional baseball players are individualists. Even now they bargain individually with their reserving club on salary terms, and they would oppose any standardization of salaries which collective bargaining might encourage. The nature of their occupation is such that organization for the purpose of collective bargaining is not feasible. Ball playing is a calling brief in duration, migratory and seasonal in character. ${ }^{238}$ Every effort to organize players in the past has proved a failure. ${ }^{207}$ Furthermore, public opinion ap-

294. See House RePort, 159-65. When organized baseball first adopted the reserve rule in 1883, all reserved players were assured of a minimum salary. When the players recognized the reserve rule in the uniform contract four years later, they insisted that the club be prohibited from reducing the salary of a reserved player without his consent. House REPORT, 159-60. At the present time, minimum salary safeguards are provided oniy for the 400 players active in the major leagues. Such players are guaranteed a salary at the rate of $\$ 5,000$ a season so long as they remain in the major leagues. Major Lesgue Rule 17(d), Hearings, 1144.

295. A bill proposed by Rep. LaGuardia (N.Y.) in 1925 virtually would have accomplished this objective. The LaGuardia bill would have imposed a ninety percent federal tax on the sale of player contracts whenever the amount involved excesded $\$ 5,000$, unless the player received the purchase price. H.R. 12102, 69th Cong., 1st Sess., 66 Cong. Rec. 2907; New York Times, Feb. 3, 1925, p. 26, col. 2.

296. See Armstrong, The Unionizatron of Basealut (unpublished thesis in Princeton University Library, 1947).

297. Aside from completely abortive attempts, four unions have existed for brief periods in the professional baseball industry. The National Brotherhood of Professional Baseball Players, recognized by the National League in 1887, found itself incapable of effecting safeguards to the reserve rule. Terming the National League "stronger than the strongest trust," it organized its own league in 1890 and expired a year later when organized baseball forced the Players League out of business. The League Players' Protective Association, organized in 1900, died quietly in 1902. The Base Ball Players' Fraternity, organized in 1913, collapsed in 1917 when it called an unstrcessful strilie. The last attempt, the American Baseball Guild, folded within a fev months after it started in 1946. HOUSE REPORT, 32-3, 172-7. The Commissioner was instrumental in defeating the last attempt to unionize. "We questioned the wisdom of it and the owners were disturbed. . . We used one man from my office, who was a former pitcher for the American Association and Rip Sewell and Jimmie Brown, and they beat the union." House REPORT, 175. A complete chronicle of the Guild's fiasco is reported in Aressisonc, op. cit. supra note 296. 
pears overwhelmingly opposed to unionization of players. ${ }^{208}$ If the reserve rule is to be perpetuated without abuse, the only practical answer appears to be congressional action.

\section{Alternative Statutory Solutions}

In order to solve the existing antitrust dilemma facing professional team sports and the courts, Congress could successfully exempt the reserve rule from harmful antitrust attack and simultaneously condition such exemption with safeguards designed to assure industrial flexibility and fairness to the players. This objective could be accomplished in three ways.

Congress itself conceivably could draft legislation defining in detail the permissive limits of monopsony power in the professional team sports industries. The task of foreseeing all possible contingencies and loopholes, however, would be tremendous. Continued revision would probably be necessary if Congress were to correct complications which are prone to develop whenever statutory regulation supplants private regulation as a check on "nattural monopoly."289

As an alternative, Congress could draft a limited exemption for the reserve rule, leaving to the courts the problem of determining what safeguards are reasonable for the protection of clubs' and players' interests. The Antitrust Subcommittee in 1952 apparently gave serious consideration to this alternative. "Such a bill," reported the Subcommittee, "would state in general terms that the antitrust laws shall not apply to reasonable rules and regulations which promote [playing] competition among baseball clubs, even though they restrain competition for players' services-as does the reserve clatuse-provided that such rules guarantee players a reasonable opportunity to advance in their profession and to be paid at a rate commensurate with their ability." Such legislation would, in effect, lay down a "rule of reason" for organized baseball. It would not, the Subcommittee pointed out hopefully, give "protection to activities designed to thwart geographic realinement of major league franchises or to arbitrary blacklisting of players in the course of a 'war'

298. In a nation-wide survey by the Institute of Public Opinion in 1946 the question was asked, "Would you like to see baseball players join labor unions?" Only 12 percent said "Yes"; 53 percent answered in the negative; 34 percent said they did not follow baseball; and one percent had no opinion. Arsstrong, op. cit. supra note 296, at 67. But see Gould, Unionism's Bid in Baseball, 115 New Repunux 134 (1946).

299. The Antitrust Subcommittee in its final report claimed "neither the requisite competence nor the desire to draft the intricate code which would be required. Congress cannot properly, nor should it, enact a comprehensive code to govern every detail of baseball's business." House REPORT, 231. The Subcommittee appears guilty of overstatement. Even if Congress were to draft a detailed code for professional team sports, such legislation would not "govern every detail" of such industries. The exemption being for one purpose-sanctioning the reserve rule-the legislation would be concerned only with a declaration of necessary safeguards to protect this monopsony grant from abuse.

300. HOUSE REPORT, 231. 
against an independent league. On the other hand, the reasonable and necessary utilization of the reserve clause would be protected against successful antitrust attack." 301

Such a course, too, has its disadvantages. Initially it would leave the determination of reasonableness to the rery parties who have frequently abused that discretion in the past. Because of the burdens and delays of litigation, judicial review of the industry's rules might be inadequate to serve as an effective check on any abuse by club owners of their monopsony power. On the other hand, too frequent resort to the courts might lead to a detailed supervision by the judiciary. ${ }^{362}$ The courts would be handicapped by not having a full perspective on the industry's problems; each case they reviewed would involve but one isolated dispute. Disagreement among courts as to what constitutes reasonable safeguards to the reserve rule might result in extended uncertainty until a body of "baseball common law" was developed.

A final alternative would be for Congress to assign to a federal administrative agency the responsibility for prescribing reasonable restraints on competition for players' services. An expert federal commission would be better equipped than Congress to draft and revise necessary safeguards to pratect this grant of monopsony power from being abused. It would also provide more disinterested rule-making and more efficient administration than court review of the reasonableness of the club owners' own regulatory agreements. Its chief drawback appears to be that few persons want it.:03 The Antitrust

301. Ibid.

302. See United States v. Paramount Pictures, Inc., \$5 F. Supp. $8 \$ 1$, \$95 (S.D.N.Y. 1949), for similar objections raised by Judge Augustus Hand cuncerning an injunetion against the motion picture companies.

303. The phobia appears to be common among sports writers and club owners. "An unthinkable step," reported Arthur Daley, sports columnist in the New York Times. "At least it will be unthinkable until the Revolution and the Communists talie over the Guvernment" Daley, Hands Off, N.Y. Times, May 27, 1952, p. 36, col. 3. Ked Smith reported equal alarm from within the ruling circles of organized baseball: "As one of the game's representatives confided during the hearings in Washington, We wanted no part of this, brother. We didn't ask for the bills or the hearings. But as long as the situation has been thrust upon us, we hope mayba we can get a crust of bread out of it. Perhaps professional sports could be exempted from the anti-trust laws. However, if that means Federal regulation of baseball-God fortid!" "Smith, Bascloll and Slatecraft, N.Y. Herald Tribune, May 23, 1952, p. 20, cul. 5.

Ban Johnson, first president of the American League (1900-27), was once "heartily in favor" of federal control of professional baseball. N.Y. Times, Jan. 1, 1927, p. 16, col. 1. See also id., Oct. 7, 1924, p. 17, col. 2; Jan. 15, 1925, p. 17, col. 1; Jan. 16, 1925, p. 11, col. 6. Senator Estes Kefauver more recently urged the same course: "It might eren be the part of wisdom for Congress to establish a Baseball Commission. If this is done, nothing more than the basic structure of the sport and the gowers of the High Commissioner should be governed. This action would eliminate any danger that ownership might tend to elect its Commissioner with the understanding that he would act principally as a figurehead for them. The institution of baseball requires discipline of ownership as well as playing personnel." Kefauver, Busthall Escapes the Tcmpter's Srate, Baseball Magazine, Oct. 1951, pp. 6, 7. 
Subcommittee summarily concluded that such federal administrative control "would be unwise in the extreme." 304

\section{Conclusion}

The net result of the congressional hearings on organized baseball has been indecisive. Organized baseball, by asking Congress for a complete exemption from the antitrust laws, lost at least for the present its opportunity for congressional approval of the reserve rule. The Antitrust Subcommittee, on the other hand, failed to lift an intolerable burden from the courts. As the ageold practices surrounding the "baseball trust" come piecemeal before the federal courts in pending or future treble damage actions, judges will face a difficult dilemma. If they follow the antitrust laws as presently interpreted by the Supreme Court, they will eliminate the business foundation of organized basebail and, in the name of protecting competitive opportunities for the players, deprive them of a livelihood. On the other hand, if the courts bend to the temptation of carving their own exemption for the game, as the Supreme Court did in 1922, they run the risk of vitiating the effectiveness of the antitrust laws in endeavors which do not share the unique problems of professional team sports. They also might thereby sanction restraints on competition in organized baseball and related sports industries which are both unnecessary and harmful. The ability of the courts to graft to the antitrust laws sensible amendments that will affect an entire industry when confronted only with the pleadings or trial record of two parties is not lightly to be presumed.

The one beneficial outgrowth of the hearings is that, for the first time since the 1920 Black Sox scandal, organized baseball is indulging in serious efforts to put its own house in order. Already, the combination has made efforts to temper the abuses of bonus payments to inexperienced rookies and of the rules on territorial rights. ${ }^{305}$

304. HOUSE REPORT, 231.

305. Following publication of the congressional report, Commissioner Frick appointed three committees to re-examine the agreements of organized baseball. One committec, according to the Commissioner, "has come through with its recommendations and the Executive Council is now recommending changes in our rules and procedure which would, among other things, strengthen and meet criticism of certain phases of our option rule; our player control rule; deficiencies in the minor league contract; shortcomings in the draft rule and would establish definitely the right of player representatives to a vote in the Executive Council on all matters pertaining to players' contracts and regulations.

"Another Committee ... has been appointed to study and bring in recommendations pointing toward the realignment of leagues. This study involving as it does real property interests, is not one that can be disposed of quickly. This Committee is making certain recommendations as to changes in the territorial rules, but they will not have their over-all long range program in shape for consideration for some time.

"The third Committee . . . was delegated the duty of evolving legislation which would eliminate to a degree the payment of tremendous bonuses to untried youngsters and would rather provide a means of paying boys on merit as they developed in their profession." Communication from Ford C. Frick to the YALE LAW Journal, dated Oct. 
Even if organized baseball succeeds in ridding itself of all the abuses stemming from its agreements in restraint of trade, Congress and the courts should not be lured into bestowing continued antitrust immunity. Industrial tyranny, however benevolent, neither recommends itself to American traditions nor forebodes to act indefinitely as a faithful public servant. If professional team sports are "natural monopsonies," the burden rests upon Congress to create a public check to replace the checks normally expected of a free marliet. The ultimate solution, therefore, to the predicament now facing the courts and organized baseball is legislation which would both exempt the reserve rule and safeguard it against abuse. Whether Congress itself, the courts, or a federal agency should determine the necessary safeguards presents a difficult legislative choice. But it is not nearly so difficult as the present alternatives now facing the courts-immunization or atomization.

30, 1952, in Yale Law Library. See also Sporting News, Nov. 12, 1952, p. 8, col. 1. The first steps of this rule revision were taken at the December, 1952, meetings when organized baseball limited bonuses to free agents to less than $\$ 5,000$ and the majors slightly modified their restrictions on club transfers. See notes 109, 126 supro. 